\title{
Perspective on identifying and characterizing the processes controlling iron speciation and residence time at the atmosphere-ocean interface
}

\author{
Nicholas Meskhidze ${ }^{\mathrm{a}, *}$, Christoph Völker ${ }^{\mathrm{b}}$, Hind A. Al-Abadleh ${ }^{\mathrm{c}}$, Katherine Barbeau ${ }^{\mathrm{d}}$, \\ Matthieu Bressac ${ }^{\mathrm{e}}$, Clifton Buck ${ }^{\mathrm{f}}$, Randelle M. Bundy ${ }^{\mathrm{g}}$, Peter Croot $^{\mathrm{h}}$, Yan Feng ${ }^{\mathrm{i}}$, Akinori Ito $^{\mathrm{j}}$, \\ Anne M. Johansen ${ }^{\mathrm{k}}$, William M. Landing ${ }^{\mathrm{l}}$, Jingqiu Mao ${ }^{\mathrm{m}}$, Stelios Myriokefalitakis ${ }^{\mathrm{n}}$, \\ Daniel Ohnemus ${ }^{\mathrm{f}}$, Benoît Pasquier ${ }^{\mathrm{o}}$, Ying Ye $^{\mathrm{b}}$
}

${ }^{a}$ North Carolina State University, Raleigh, NC 27695, USA

${ }^{\mathrm{b}}$ Alfred Wegener Institute for Polar and Marine Research, Am Handelshafen 12, 27570 Bremerhaven, Germany

${ }^{\mathrm{c}}$ Department of Chemistry and Biochemistry, Wilfrid Laurier University, Waterloo, ON, Canada

${ }^{\mathrm{d}}$ Geosciences Research Division, Scripps Institution of Oceanography, La Jolla, CA 92093, USA

${ }^{\mathrm{e}}$ Institute for Marine and Antarctic Studies, University of Tasmania, Hobart, Tasmania, Australia

${ }^{\mathrm{f}}$ Skidaway Institute of Oceanography, University of Georgia, Savannah, GA 31411, USA

${ }^{\mathrm{g}}$ School of Oceanography, University of Washington, Seattle, WA 98195, USA

${ }^{\mathrm{h}}$ School of Natural Sciences and Ryan Institute, National University of Ireland Galway, Galway H91 TK33, Ireland

${ }^{i}$ Environmental Science Division, Argonne National Laboratory, Lemont, IL 60439, USA

${ }^{\mathrm{j}}$ Yokohama Institute for Earth Sciences, JAMSTEC, Yokohama, Kanagawa 236-0001, Japan

${ }^{\mathrm{k}}$ Department of Chemistry, Central Washington University, Ellensburg, WA 98926, USA

${ }^{1}$ Department of Earth, Ocean, and Atmospheric Science, Florida State University, Tallahassee, FL 32306, USA

${ }^{\mathrm{m}}$ Department of Chemistry and Biochemistry, University of Alaska Fairbanks, Fairbanks, AK 99775, USA

${ }^{\mathrm{n}}$ Institute for Environmental Research and Sustainable Development (IERSD), National Observatory of Athens, GR-15236 Palea Penteli, Greece

${ }^{\circ}$ Department of Earth System Science, University of California, Irvine, CA 92697, USA

A R T I C L E I N F O

\section{Keywords:}

Atmosphere-ocean interaction

Iron biogeochemistry

Bioaccessible and bioavailable iron

Atmospheric and oceanic models

\begin{abstract}
A B S T R A C T
It is well recognized that the atmospheric deposition of iron (Fe) affects ocean productivity, atmospheric $\mathrm{CO}_{2}$ uptake, ecosystem diversity, and overall climate. Despite significant advances in measurement techniques and modeling efforts, discrepancies persist between observations and models that hinder accurate predictions of processes and their global effects. Here, we provide an assessment report on where the current state of knowledge is and where future research emphasis would have the highest impact in furthering the field of Fe atmosphere-ocean biogeochemical cycle. These results were determined through consensus reached by diverse researchers from the oceanographic and atmospheric science communities with backgrounds in laboratory and in situ measurements, modeling, and remote sensing. We discuss i) novel measurement methodologies and instrumentation that allow detection and speciation of different forms and oxidation states of Fe in deliquesced mineral aerosol, cloud/rainwater, and seawater; ii) oceanic models that treat Fe cycling with several external sources and sinks, dissolved, colloidal, particulate, inorganic, and organic ligand-complexed forms of Fe, as well as $\mathrm{Fe}$ in detritus and phytoplankton; and iii) atmospheric models that consider natural and anthropogenic sources of Fe, mobilization of Fe in mineral aerosols due to the dissolution of Fe-oxides and Fe-substituted aluminosilicates through proton-promoted, organic ligand-promoted, and photo-reductive mechanisms. In addition, the study identifies existing challenges and disconnects (both fundamental and methodological) such as i) inconsistencies in Fe nomenclature and the definition of bioavailable Fe between oceanic and atmospheric disciplines, and ii) the lack of characterization of the processes controlling Fe speciation and residence time at the atmosphere-ocean interface. Such challenges are undoubtedly caused by extremely low concentrations, short lifetime, and the myriad of physical, (photo)chemical, and biological processes affecting global biogeochemical cycling of Fe. However, we also argue that the historical division (separate treatment of Fe biogeochemistry in oceanic and atmospheric disciplines) and the classical funding structures (that often create obstacles for transdisciplinary collaboration) are also hampering the advancement of knowledge in the field. Finally, the study
\end{abstract}

\footnotetext{
* Corresponding author at: Marine Earth and Atmospheric Sciences, North Carolina State University, Raleigh, NC, USA.

E-mail address: nmeskhidze@ncsu.edu (N. Meskhidze).
} 
provides some specific ideas and guidelines for laboratory studies, field measurements, and modeling research required for improved characterization of global biogeochemical cycling of Fe in relationship with other trace elements and essential nutrients. The report is intended to aid scientists in their work related to Fe biogeochemistry as well as program managers at the relevant funding agencies.

\section{Introduction}

Earth System Models (ESMs) now pay particular attention to interactions between the atmosphere and the ocean ecosystems, in response to the highlighted need for improved representation of climate forcing and feedbacks (IPCC, 2013). These interactions have implications for trace gas exchange, the bidirectional fluxes of particulates, and the overall global energy budget. The synthesis of in situ-observational and iron fertilization studies (e.g., Boyd et al., 2007) has shown that, in addition to nitrogen and phosphorus, iron ( $\mathrm{Fe}$ ) is one of the major limiting nutrients that exerts a direct control on ocean productivity and carbon export not only in the High Nutrient, Low Chlorophyll (HNLC) regions but in many other regions globally (Moore et al., 2013). This finding is also reproduced by global ocean biogeochemical models (Fung et al., 2000; Moore and Doney, 2007). Atmospheric supply of Fe (including mineral dust, volcanic, biomass burning, and anthropogenic aerosols), is considered to be an important external Fe source for the open ocean (Duce and Tindale, 1991; Jickells et al., 2005; Tagliabue et al., 2017). Studies have shown, that in addition to the direct forcing of climate through its impact on ocean productivity and atmospheric $\mathrm{CO}_{2}$ uptake, the atmospheric deposition of Fe could affect ocean ecosystem diversity and, as a result, climate feedbacks (Moore et al., 2004; Krishnamurthy et al., 2010).

All known forms of life require Fe in several physiological functions: Iron is needed in electron transport around photosystems I and II (Raven et al., 1999), in the enzymes nitrogenase and nitrate reductase, which catalyze redox transformations of nitrogen (e.g., Raven, 1988), and in the cytochrome P450 superfamily of proteins, which catalyzes a large number of different reactions in organisms as diverse as archaea and animals (Danielson, 2002). However, acquisition of Fe by aquatic microorganisms is difficult, as the oxidizing environment of the oceans limits concentrations of aqueous inorganic Fe to sub-picomolar levels, orders of magnitude less than what is required to sustain oceanic biomass and primary production (Liu and Millero, 2002; Johnson et al., 1997). The solubility of inorganic iron in oxygenated seawater solutions can be increased in the presence of organic ligands or chelators. It is estimated that $>99 \%$ of bioavailable Fe (i.e., Fe that can be taken up by the biota) is chelated by organic ligands (Rue and Bruland, 1995; Gledhill and Buck, 2012). As the residence time of ligand-complexed Fe is long (months to years, Hayes et al., 2018), oceans can maintain levels of bioavailable Fe well above the concentration limits of aqueous inorganic forms.

Characterization of the ocean's biogeochemical cycles requires quantitative knowledge of atmospheric sources of bioavailable Fe (Fung et al., 2000; Moore et al., 2004; Parekh et al., 2004; Moore and Doney, 2007; Krishnamurthy et al., 2010; Okin et al., 2011; Sholkovitz et al., 2012; Mahowald et al., 2018). Over the past decades, significant progress has been made in treating atmospheric sources of Fe in both atmospheric and oceanic global biogeochemical models. However, due to historical division, the global biogeochemical cycling of Fe has been treated separately in oceanic and atmospheric disciplines. This division has created several challenges that impede future progress. As a consequence, our ability to explore the impact of atmospheric nutrient deposition on phytoplankton abundance, productivity, and diversity is still limited, hampering confident projections of human-induced effects on the carbon cycle and climate.

In marine sciences, Fe species in seawater are operationally differentiated using membrane filtration and can be present in two oxidation states, namely ferrous (Fe(II)) and ferric (Fe(III)) iron. Particulate Fe
(PFe) is retained by a $0.2 \mu \mathrm{m}$ filter and is assumed to gravitationally settle. Dissolved Fe (DFe) that passes through a $0.2 \mu \mathrm{m}$ filter, soluble Fe (SFe) that passes through a $0.02 \mu \mathrm{m}$ filter, and colloidal $\mathrm{Fe}(\mathrm{CFe})$ that passes through a $0.2 \mu \mathrm{m}$ but is retained by a $0.02 \mu \mathrm{m}$ filter, are all assumed to be neutrally buoyant and be transported along water currents and turbulent eddies. The DFe, $\mathrm{CFe}$, and $\mathrm{SFe}$ forms of $\mathrm{Fe}$ are often assumed to be ligand-bound and considered to be bioavailable for phytoplankton in ocean biogeochemistry models (Raiswell and Canfield, 2012). Using such operational definitions, ocean models can then explicitly consider $\mathrm{Fe}(\mathrm{II}) / \mathrm{Fe}(\mathrm{III})$ cycling with external sources (mineral dust deposition, sediments, and hydrothermal), sinks (loss to the sediment, either as scavenged Fe on particles (Turekian, 1977), or as part of the buried organic matter), different forms of Fe (dissolved vs. colloidal or particulate, inorganic vs. organic), and $\mathrm{Fe}$ in detritus and phytoplankton (diazotrophs, large and small phytoplankton) (e.g., Parekh et al., 2005; Dunne et al., 2012; Aumont et al., 2015). Most ocean biogeochemical models use prescribed dust-deposition fluxes from atmospheric models as their atmospheric Fe input field, assuming both the weight fraction of $\mathrm{Fe}$ in mineral dust and the bioavailability of dustdeposited Fe to be constants. The concentration of Fe-binding ligands in seawater in models is often a fixed value as well. Oceanic biogeochemistry models to some extent reproduce the observed mean dissolved Fe concentrations in the surface ocean, albeit through the use of tuned scavenging rates to balance the large range $(0.08-1.68 \mathrm{Tg} \mathrm{Fe}$ $\mathrm{yr}^{-1}$ ) in soluble Fe fluxes (Tagliabue et al., 2016). The sources and sinks of DFe, which are generally colocated, cannot be inferred solely from the geographical distribution of DFe (Pasquier and Holzer, 2017). Some recent attempts have been made to include more processes-oriented mechanisms for the solubility of dust-deposited Fe, e.g., spatially varying ligand concentrations, particulate material other than particulate organic carbon (Ye and Völker, 2017), and some of the first parameterizations of variable aerosol Fe solubility (Albani et al., 2016). The spatiotemporal variability of ligands (modeled as one ligand class with fixed binding strength) is either described prognostically (Völker and Tagliabue, 2015) or related to apparent oxygen utilization and/or semilabile dissolved organic carbon (DOC) (Misumi et al., 2013). Prognostic ligand models are more mechanistic but use highly uncertain assumptions on the biogenic sources of ligands and their breakdown processes. Recent studies have also begun to question the idea that nearly all DFe in surface oceans is ligand-complexed (Fitzsimmons et al., 2015a, 2015b) since nanoparticulates (defined here as inorganic forms of amorphous-crystalline $\mathrm{Fe}$ matrices $<0.2 \mu \mathrm{m}$ in diameter), are small enough to fall into the dissolved size fraction. Bioavailability of Fe in seawater is controlled by numerous additional factors including processes mediated by the environment as well as controlled by microbes, such as light, temperature, excretion of siderophores and varying microbial uptake mechanisms (Hudson and Morel, 1990; Wilhelm and Trick, 1994; Maldonado and Price, 2001; Shaked and Lis, 2012; Morrissey et al., 2015). The matter is further complicated by the fact that $\mathrm{SFe}, \mathrm{CFe}$, and even PFe could be indirectly bioavailable to some groups (Chen and Wang, 2001; Hassler et al., 2011a, 2011b; Kanna and Nishioka, 2016). All these processes are hardly (if at all) resolved in ocean biogeochemical models.

Since quantifying the bioavailability of Fe in aerosols is complex, atmospheric models have largely focused on soluble forms of $\mathrm{Fe}$ in deliquesced aerosol solution and cloud water. Atmospheric Fe biogeochemistry models now routinely consider mineralogy of wind-blown dust and $\mathrm{Fe}$ emanating from anthropogenic (combustion, biomass burning) aerosols. Atmospheric models also simulate the secondary 
formation of soluble Fe in the atmosphere due to the dissolution of Feoxides and Fe-substituted aluminosilicates through proton-promoted, organic ligand-promoted, and photo-reductive mechanisms (Myriokefalitakis et al., 2018). Fe in atmospheric aerosols may be present in different forms, i.e., crystalline and amorphous Fe-(oxy)hydroxides (e.g., hematite, goethite, and ferrihydrite), Fe-substituted into aluminosilicate minerals, Fe-rich nanoparticles, and Fe-organic complexes (Claquin et al., 1999; Nickovic et al., 2013; Shi et al., 2009; Cheize et al., 2012) and either in the Fe(III) or Fe(II) oxidation states (Deguillaume et al., 2005; Bhattachan et al., 2016). Therefore, modelto-model and model-to-surface observation comparisons of soluble Fe remain hardelusive. To overcome this difficulty, Myriokefalitakis et al. (2018) suggested using labile Fe (LFe) to represent the total soluble Fe in simulated atmospheric aerosol. Current atmospheric models are able to simulate the main features of atmospheric concentrations and deposition fluxes of labile Fe with an estimated global mean LFe flux to the ocean between 0.17 and $0.42 \mathrm{Tg} \mathrm{Fe} \mathrm{yr}^{-1}$ (Myriokefalitakis et al., 2018), though large uncertainties remain in the absolute amount of LFe flux to different ocean regions (Myriokefalitakis et al., 2018). The introduction of LFe simplifies Fe representation in atmospheric models and helps with model-to-model intercomparison. However, many challenges and disconnects (both fundamental and methodological) still remain. For example, models calculate LFe based on the chemical reactions with prescribed (commonly $0.45 \%$ ) dissolved Fe fraction at the source region, which are routinely compared to measurements that use both 0.45 or $0.2 \mu \mathrm{m}$ filter sizes for separation of soluble and insoluble fractions. Furthermore, aerosol-derived Fe in these sized particles (nanoparticulate colloids) can be comprised of amorphous and crystalline Fe-(oxyhydr)oxides, Fe-substituted alumino-silicates, and other Fe-rich nanoparticles (von der Heyden et al., 2012) that may not be bioavailable in seawater (e.g., Rich and Morel, 1990).

Finally, neither atmospheric nor ocean biogeochemistry models consider the processes that influence physicochemical speciation of $\mathrm{Fe}$ at the atmosphere-ocean interface on the time scale of minutes to days and at the spatial resolution of tens of meters (in vertical resolution) to several kilometers (in horizontal). Considering that in several minutes after deposition, a very small fraction $(\sim 10 \%)$ of atmospherically delivered inorganic soluble Fe can remain bioavailable in seawater devoid of organics (e.g., Santana-Casiano et al., 2005; Gilbert et al., 2007), the atmosphere-ocean interface remains one of the most uncertain components of $\mathrm{Fe}$ biogeochemical modeling. In general, the ability of aerosol LFe to influence the DFe budget of the oceans largely depends on two factors: i) the amount of LFe delivered through atmospheric pathways, and ii) the likelihood that LFe will become complexed by the Fe-binding ligands in the ocean. Although ligand concentrations in the ocean often exceed DFe (Boyd and Ellwood, 2010), only a small fraction of LFe entering the ocean may remain as ligand-complexed DFe. Aerosol LFe entering the ocean in $\mathrm{Fe}(\mathrm{II})$ or Fe(III) inorganic forms (Deguillaume et al., 2005; Bhattachan et al., 2016) will have a short lifetime unless they become quickly complexed by marine organics (Meskhidze et al., 2017). Within minutes Fe(II) is oxidized to Fe(III) in seawater (Rose and Waite, 2003). The half-life of Fe(II) can extend to an hour in cold $\left(<5^{\circ} \mathrm{C}\right)$ polar waters. Due to its low solubility, Fe(III) rapidly forms nano-particulate colloids and/or gets scavenged by oceanic particles. The half-life of $10-30 \mathrm{~h}$ was calculated during an artificial addition of LFe to surface ocean (e.g., Gordon et al., 1998). It is true, that a high concentration of organic ligands can increase the retention of atmospheric LFe as DFe in the ocean (Gordon et al., 1998; Bowie et al., 2001). However, because depositions of large amounts of aerosol LFe are highly episodic in nature, with 30 to $80 \%$ of the annually averaged dust deposition occurring on $\sim 5 \%$ of the days (Mahowald et al., 2009), Fe entering the surface ocean during one such event could easily consume all available ocean organic ligand, thereby reducing the lifetime of LFe (Meskhidze et al., 2017).

Several reviews have covered the deposition of bioavailable iron from dust and the processes important in determining its effect from different angles (Baker and Croot, 2010; Guieu et al., 2014; Baker et al., 2016; Mahowald et al., 2018; Kanakidou et al., 2018), and we refer to them where appropriate. In this article, we build on previous studies and attempt to highlight the most critical open questions and propose possible solutions regarding the aerosol $\mathrm{Fe}$ at the atmosphere-ocean interface. We also attempt to clear-up the nomenclature used by oceanic and atmospheric researchers and develop a list of priorities and rank them based on their feasibility and impact.

\section{Material and methods}

Seventeen scientists from seven countries convened in Telluride, CO on July 30-August 3, 2018 to present their experimental and modeling studies related to atmospheric delivery of aerosol Fe and its contribution to the dissolved Fe inventory of the ocean. The workshop brought together established scientists and young researchers $\mathrm{PhD}$ students and early career researchers who received their $\mathrm{PhD}$ within 8 years) to provide opportunities for professional interactions in a focused and productive forum. More than one-third of the invited researchers were female scientists. The individual presentations were followed by two breakout sessions and a summary session. Charges to working groups were laid out and distributed to all participants ahead of time. Each breakout session had a moderator/discussion leader and a rapporteur. The discussions in the breakout sessions were structured by the thematics and were designed to identify the most critical open questions concerning the sources, chemical forms, lifetime, and bioavailability of atmospherically delivered Fe. These discussions are summarized as individual sections of the manuscript. The discussions in the summary session were focused by topic and ubject (contributed by the participants ahead of the workshop) and classified into four categories separated by (i) environmental domains (atmosphere vs. ocean) and (ii) study approach (model vs. observation): Atmospheric Model Representation, Ocean Model Representation, Atmospheric Measurement Methodologies, and Ocean Measurement Methodologies. For each topic, the following aspects were ranked through brainstorming: the current level of understanding, the impact that a full understanding would have in the field, and the resources that would be needed. Individual responses were collected, and 'low', 'medium', and 'high' level of understanding was assigned to each topic based on the consensus achieved by the majority of workshop participants. The order of listing of topics does not convey any indication of priority settings by the attendees. The developed Science Prioritization Matrix (see Sec. 12) that identifies the areas of investigation by the magnitude of their impact on proposed science is meant to inform program managers as well as researchers working in different fields.

\section{Fe nomenclature and the fraction of bioavailable Fe of ocean- deposited aerosols}

Comprehensive characterization of the effects of atmospheric deposition of $\mathrm{Fe}$ on surface ocean productivity requires knowledge of aerosol-Fe bioavailability. However, the concept of Fe bioavailability in seawater is extremely complex and poorly defined. The bioavailability of $\mathrm{Fe}$ in seawater varies between different bacterial and phytoplankton taxa or species within taxa, due to differences in the cellular surface area (Lis et al., 2015) and the existence of a wide range of Fe uptake mechanisms that are specialized for the transport of various chemical forms of Fe (Morel et al., 2008; Maldonado and Price, 2001; Morrissey et al., 2015; Wilhelm and Trick, 1994). These processes can also be influenced by other trace metals (such as for copper-dependent surface reductases, Semeniuk et al., 2016), solution $\mathrm{pH}$, and carbonate ion concentration (McQuaid et al., 2018). In addition, Fe bioavailability is linked to post-depositional processes in the ocean influenced by the physicochemical state of the ocean, Fe speciation, light, and microbial interactions (Brévière and the SOLAS Scientific Steering Committee, 2016). Since the main objective for improved characterization of 
biogeochemical cycling of $\mathrm{Fe}$ in the atmosphere is better quantification of its effects on ocean biological productivity and carbon uptake, we recommend adopting similar definitions that are based on operationally determined forms of $\mathrm{Fe}$ in the atmospheric and oceanic science communities, as summarized in Table 1. In terms of Fe contained in various particle sizes, as measured through filtration, $\mathrm{PFe}, \mathrm{CFe}, \mathrm{DFe}$, and $\mathrm{SFe}$, are the most appropriate definitions, while in terms of oxidation state, $\mathrm{Fe}(\mathrm{II}) / \mathrm{Fe}(\mathrm{III})$ would be applicable. These operational definitions of aerosol Fe could be applied to measurements of the deliquesced aerosol solution, cloud/rainwater, and seawater. However, to highlight the differences in chemical forms and biological uptake potential between aerosol DFe and seawater DFe we suggest adapting definitions similar to those suggested by Semple et al. (2004). By separating the "bioavailable" compound, which is defined as the freely available Fe that can cross an organism's cellular membrane within the medium that the organism inhabits, from the "bioaccessible" compound, which is the Fe that is potentially chemically accessible to cross an organism's cellular membrane from the environment. DFe in the ocean can be viewed as the bioavailable form of Fe. Once transfer across the membrane occurs, further storage, transformation, assimilation, or degradation can take place within the organism. It is important to note that bioavailability is always specific to an organism, and not all DFe is bioavailable to every organism.

Aerosol DFe should not be viewed as bioavailable for ocean biota, because as stated above, the term "bioavailable" implies immediacy, i.e., what is available at that time (Semple et al., 2004). Instead, we suggest aerosol DFe be viewed as bioaccessible, i.e., a compound which is in a form that is potentially bioavailable. Once it reaches the surface ocean, bioaccessible Fe may: 1) be immediately available to cross the organisms cellular membrane or get chelated with seawater organic ligands and enter oceanic DFe pool, 2) be transitioned from dissolved to (oxy)hydroxides, or scavenged into sinking particles and be physically removed from the surface ocean, or 3 ) become available to the organism after a period of time, i.e., undergo some transformation before it can be transported across the cell membrane, resulting in possible kinetic impediments to uptake. We acknowledge that, due to the complexity of different Fe uptake mechanisms by bacteria and eukaryotic phytoplankton, we do not have a complete understanding of which operationally defined forms of Fe are bioaccessible and to which groups of microbes. For example, further progress in the study of uptake mechanisms may lead to a reevaluation of the concept of bioavailability and the extension of the bioavailable fraction from the currently assumed forms (inorganic and complexed by weak organic ligands) to other forms such as small colloids. Nevertheless, we believe that the introduction of a bioaccessible form of aerosol Fe will motivate future studies involving genomics, transcriptomics, or similar techniques and contribute to our understanding of the biogeochemical transformation of Fe at the atmosphere-ocean interface. Studies may involve the understanding of the structure of the genome (through gene mapping, DNA sequencing, RNA transcripts, molecular mechanisms for Fe assimilation in a cell), the interplay of genetic and environmental factors in algae and heterotrophic bacteria, and characterization of the concentrations and binding strengths of Fe-binding organic ligands. Given that Fe cycles readily between the Fe(II) and Fe(III) oxidation states in the atmosphere and the oceans, it will be essential to learn how each redox form is affected by the processes listed above. When possible, we recommend $\mathrm{Fe}(\mathrm{II})$ and $\mathrm{Fe}(\mathrm{III})$ to be reported separately in atmospheric models and in situ measurement, as they together are considered the redox-active pool of Fe. Finally, future laboratory and in situ studies should clearly report the measurement conditions, the methodology employed, and the instrumentation used in order to accurately define which chemical form of $\mathrm{Fe}$ is appropriate for the terminology used. Likewise, modeling results should clearly state which of the various chemical forms of $\mathrm{Fe}$ are most comparable to their results.

\section{Standardization of aerosol Fe measurements}

The standardization of aerosol Fe measurement methodologies for atmospheric and oceanic disciplines is critical for improved representation of $\mathrm{Fe}$ biogeochemistry. Currently, different research groups use a range of different leaching techniques ('batch' leaching, 'flow-through' leaching, and a combination of these two) with different types of Fe extraction solutions (seawater or high-purity deionized (DI) water), $\mathrm{pH}$ values of the solutions (from $<2$ to $>8$ ), extraction times (from minutes to days), and (photo)reductant agents (oxalic, ascorbic, glyoxalic, and pyruvic acids) leading to large discrepancies in SFeS results (e.g., Sholkovitz et al., 2012). In addition to the range of different methods used for Fe extraction, different groups are using different operational definitions for fractional solubility of Fe in mineral dust. The SFeS is defined as the material that passes through a $0.2 \mu \mathrm{m}$ pore diameter filters and commonly detected through Inductively Coupled Plasma-Optical Emission Spectroscopy (ICP-OES), or High Resolution Inductively Coupled Plasma-Mass Spectrometry (HR-ICPMS) (e.g., Lim and Jickells, 1990; Zhuang et al., 1990; Bonnet and Guieu, 2004; Baker et al., 2006; Mackie et al., 2006; Wu et al., 2007; Buck et al., 2006, 2010; Aguilar-Islas et al., 2010; Paris et al., 2011). The determination of dissolved $\mathrm{Fe}$ also involves chelation/solvent extraction methods (Landing and Bruland, 1987; Martin and Gordon, 1988), co-precipitation methods (Wu and Boyle, 1998), chelation/solid phase partitioning (Wells and Bruland, 1998), voltammetric techniques (Rue and Bruland, 1995; Gledhill and van den Berg, 1995), and the use of chelating ion exchange resins (Elrod et al., 1991; Obata et al., 1993; Measures et al., 1995; Bowie et al., 1998; Lohan et al., 2005). Here we follow the recommendation of Baker et al. (2016) and suggest finegrained Arizona Test Dust (with particle diameter $<1 \mu \mathrm{m}$ representing up to $90 \%$ of the particle volume, ISO -12,103-1) to be used by different investigators to standardize the results of their leach techniques for determining DFe from aerosols, because of its reproducibility and a good imitation of long-range transported mineral dust over the open ocean. To describe short-term (seconds to minutes) and long-term (days to months) release of bioaccessible Fe from aerosol deposition to the ocean, two sequential leaches of the sample-collection filters (see Table 2) can be used. In the first one, the sample leaching is conducted by quickly $(\sim 10 \mathrm{~s}$ exposure time) passing Millipore Milli-Q $\left(>18 \mathrm{M} \Omega \mathrm{cm}^{1}\right.$ ) ultrapure water through an aerosol filter by applying a vacuum (Buck et al., 2006; Morton et al., 2013). This leaching technique is designed to yielding a measure of the "instantaneous" watersoluble ("DI soluble") Fe fraction and can be viewed as representative of lower bound on aerosol solubility. In the second one, the sample is in the contact with a leach solution for $2 \mathrm{~h}$ (with a heating step), $25 \%$ acetic acid (HAc), and $0.02 \mathrm{M}$ hydroxylamine hydrochloride solution are added to the vial as described in Berger et al. (2008). The "Bergerleached" Fe sets the higher bound on solubility. Both of these leaching solutions will yield a fraction of the bioaccessible Fe that can enter the oceanic DFe pool. However, the DI soluble will correspond to the fraction of aerosol Fe that is immediately available for the uptake, while the Berger-leached aerosol Fe may become bioavailable with some kinetic impediments to uptake i.e., after being processed through an acidic, reducing zooplankton or protozoan gut, mobilized from particulate forms through interactions with siderophores, or from redox

Table 1

Suggested operational definitions of Fe to be used in deliquesced aerosol solution, cloud/rainwater, and seawater.

\begin{tabular}{|c|c|c|c|}
\hline Form & Oxidation state & Symbol & Definition \\
\hline Particulate & $\mathrm{Fe}(\mathrm{II}) / \mathrm{Fe}(\mathrm{III})$ & $\mathrm{PFe}$ & Retained by $0.2 \mu \mathrm{m}$ membrane filter \\
\hline Colloidal & & $\mathrm{CFe}$ & $\begin{array}{l}\text { Passes through a } 0.2 \mu \mathrm{m} \text { but is retained } \\
\text { by a } 0.02 \mu \mathrm{m} \text { filter }\end{array}$ \\
\hline Dissolved & & $\mathrm{DFe}$ & Passes through $0.2 \mu \mathrm{m}$ filter \\
\hline Soluble & & $\mathrm{SFe}$ & Passes through a $0.02 \mu \mathrm{m}$ filter \\
\hline
\end{tabular}


Table 2

Suggested measurement standards: leaching methods for atmospheric dust samples.

\begin{tabular}{ll}
\hline Leach type & Definition \\
\hline $\begin{array}{l}\text { DI soluble } \\
\text { Berger }\end{array}$ & Low-solubility limit: measured by vacuum-suction of $100 \mathrm{~mL}$ of ultra-high purity (UHP) water through the filter within $\sim 10 \mathrm{~s}$ \\
High-solubility limit: measured by addition of $4.4 \mathrm{M}$ acetic acid (HAc) with $0.02 \mathrm{M}$ hydroxylamine hydrochloride solution
\end{tabular}

cycling (both photo-induced and associated with reducing micro-environments in fecal pellets and organic aggregates). Even though such descriptions are highly simplistic and may not be appropriate to fully characterize the bioavailable fraction of aerosol Fe in the ocean (Shaked and Lis, 2012), they can be used by modelers to prescribe a range of bioaccessibility to atmospheric Fe (Mackey et al., 2015).

We recommend the sample collection and seawater DFe speciation analysis be followed as outlined in the GEOTRACES Cruise and Methods Manual (Cutter, 2018). The complete details of DFe analyses can be found in Rijkenberg et al. (2014) and Sedwick et al. (2015). Briefly, samples for DFe should be separately collected from speciation samples in acid-cleaned low-density polyethylene bottles. These samples should then be filtered through $<0.2 \mu \mathrm{m}$ filters. Samples should be acidified to $0.024 \mathrm{M}$ hydrochloric acid ( $\mathrm{HCl}$ ) with high purity $\mathrm{HCl}$ (Johnson et al., 2007). Dissolved Fe(II) can be determined by flow injection analysis with in-line preconcentration and chemiluminescence detection. DFe can be determined by flow injection analysis with in-line preconcentration on chelating resin followed by analysis using colorimetric technique or IC-PMS (Biller and Bruland, 2012; Rijkenberg et al., 2014; Sedwick et al., 2015; Buck et al., 2016; Wuttig et al., 2019).

\section{Constraining depositional fluxes}

Constraining depositional fluxes of aerosols is one of the major problems in the global biogeochemical cycling of atmospheric Fe. Particle removal by wet deposition processes (including both convective updraft rainout/in-cloud wet scavenging and washout from large-scale precipitation) is the major source $(\sim 80 \%)$ of aerosol $\mathrm{Fe}$ to the surface of the open ocean (Fan et al., 2006). Both the magnitude of total depositional value and spatiotemporal variability of atmospheric fluxes of Fe remain unconstrained in global models because rainwater samples are difficult to collect on a routine basis, particularly over remote ocean areas. Similarly, the magnitude and distribution of DFe input to the ocean cannot be constrained by the observed distributions of marine DFe alone using global marine biogeochemistry models because of the colocation of the compensating DFe deposition and scavenging rates (Pasquier and Holzer, 2017).

Deriving the atmospheric flux of radionuclide beryllium-7 $\left({ }^{7} \mathrm{Be}\right)$ from its ocean inventory may provide the means to link atmospheric concentrations and fluxes of DFe (Baker et al., 2016). The ${ }^{7} \mathrm{Be}$ isotope (53.3-day half-life) is produced by cosmic-ray spallation and is deposited to the ocean surface primarily by precipitation. Under steadystate conditions in the open ocean, the removal rate of ${ }^{7} \mathrm{Be}$ from the upper ocean due to decay should be equal to its atmospheric deposition rate which is in turn equal to the aerosol ${ }^{7} \mathrm{Be}$ concentration multiplied by a bulk deposition velocity that accounts for both wet and dry deposition processes. Kadko et al. (2015) used bulk deposition velocities derived in this way to calculate fluxes of other aerosol species, such as total and soluble Fe in mineral dust, producing flux estimates that were within $40-50 \%$ of direct measurements. The ${ }^{7} \mathrm{Be}$ method is advantageous, as it can provide fluxes for atmospherically delivered bioaccessible DFe.

Application of the ${ }^{7} \mathrm{Be}$ method may be limited to areas where wet deposition dominates. Additional aspects to consider are the interaction of rainwater with the ocean surface microlayer (SML), the variability in size-dependent wet removal efficiency for particles in the accumulation mode (with particle diameters within $0.1-1 \mu \mathrm{m}$; such as for anthropogenic particles), and the strong seasonal variability in atmospheric aerosol concentrations relative to that of ${ }^{7} \mathrm{Be}$. Suggested future studies should explore the application of the ${ }^{7} \mathrm{Be}$-tracer technique to aerosol dry deposition fluxes. The ${ }^{7} \mathrm{Be}$ method needs to be tested in different ocean basins characterized by a wide range of precipitation rates to obtain Fe fluxes that could be used to constrain global models of Fe deposition. Examples of possible study locations include sites of longterm time series which have available facilities, e.g., Cape Verde Islands, Bermuda, Hawaii, or in the Mediterranean. Other suggestions for reducing the uncertainty in aerosol fluxes were to run an offline ${ }^{7} \mathrm{Be}$ atmospheric model (Liu et al., 2001) and compare the data with ocean measurements, deploying automated rain collectors on ships of opportunity, collecting atmospheric black carbon concentration and size distribution data concurrently with rainwater samples, and collecting particle-size spectra in the water column. Future activities should focus on capturing representative fluxes of aerosols to the ocean on a seasonal basis, not just during the extremes (which is often the case for mineral dust deposition). Fe isotopes present an additional way to constrain the source (lithogenic vs. anthropogenic) of iron in deposition (Waeles et al., 2007; Conway and John, 2014; Conway et al., 2019) and should be considered further.

\section{Anthropogenic and biomass burning aerosols: Fe solubility and behavior}

Over the open ocean, the global deposition flux of DFe from mineral dust is considerably higher than the flux of Fe from anthropogenic (largely combustion) and biomass-burning aerosols (Myriokefalitakis et al., 2018). However, due to their spatiotemporal distribution and higher fractional Fe solubility (Chuang et al., 2005; Guieu et al., 2005; Sedwick et al., 2007; Sholkovitz et al., 2009), combustion aerosols may play an important role in influencing the fluxes of DFe over oceanic regions with little dust input, downwind from industrialized regions, and/or near major shipping routes (Ito et al., 2019a). Furthermore, an ocean biogeochemistry model suggests that pyrogenic Fe-containing aerosols stimulate the marine productivity more efficiently than lithogenic aerosols, especially in the Pacific and Southern Ocean (Ito et al., 2019). Because anthropogenic aerosols are small in size (i.e., $<1 \mu \mathrm{m}$ ) and found predominantly within the accumulation mode, the total amount collected on the filters is also small, complicating efforts to characterize the oxidation forms and mineralogy of aerosol Fe. Due to their small size and chemical composition, the latter of which controls particle hygroscopicity, dry and wet removal rates of anthropogenic aerosols could be very different from those of mineral dust. In-situ studies on the effects of anthropogenic aerosols are difficult to carry out because even at relatively high concentration, anthropogenic aerosols might not deposit sufficient quantities of DFe to relieve Fe limitation and support visible, large-scale phytoplankton blooms (Meskhidze et al., 2005; Solmon et al., 2009).

There is a need for improved characterization of the source-specific solubility in various types of combustion-sourced aerosols, and an assessment of the global mean and spatiotemporal fluxes of combustionrelated DFe. To that end, other anthropogenic tracers, like nitrogen $(\mathrm{N})$ or aerosol trace-metals, such as vanadium (V) or nickel (Ni) can be used for constraining anthropogenic sources of Fe. Synchrotron-based X-ray microspectroscopy techniques also provide a useful tool to characterize atmospheric concentration and oxidations states of $\mathrm{Fe}$ (Fe(II) or Fe(III)) and trace metals in anthropogenic aerosols in sub-micron size ranges (Oakes et al., 2012; Ingall et al., 2018). Improved assessments of 
bioaccessible Fe fluxes from biomass-burning aerosols also require accurate estimates of the amount of biomass consumed during forest fires, the location of the fires relative to the availability of fuels, the timing of the fires during the burning season, and the aerosol transport from forest fire emissions (including the plume injection height and the vertical distribution of smoke) (Ito, 2011).

\section{The importance of the surface microlayer}

The SML represents a thin $(\sim 50-150 \mu \mathrm{m}$ thick) gelatinous boundary between the atmosphere and ocean consisting of hydrophobic surfactants (e.g., fatty acids), hydrophilic surfactants (e.g., lipopolysaccharides), and complex assemblages of different microorganisms (Henrichs and Williams, 1985; Kuznetsova and Lee, 2002; Aller et al., 2005; Hawkins and Russell, 2010; Cunliffe et al., 2013). The importance of the SML for Fe biogeochemistry has been recognized since the early 1970s. Studies suggest that aerosols, deposited through wet or dry deposition, often become trapped, leading to a considerable enrichment in the SML of estuarine, coastal, and open ocean areas (Duce et al., 1972; Piotrowicz et al., 1972; Cunliffe et al., 2013; Tovar-Sánchez et al., 2014; Wurl et al., 2017). The SML is a dynamic physicochemical barrier which is characterized by chemical properties very different from the bulk seawater (Liss and Duce, 2005; Zhang et al., 2003) and populated by large amounts of bacteria (Cunliffe et al., 2013). The SML could modify particle aggregation properties after both wet and dry deposition of mineral dust and influence the speciation and residence time of $\mathrm{Fe}$ in the surface ocean. Residence times for DFe and PFe in the SML are potentially long enough (minutes to hours) for Fe to undergo (photo) chemical and biological alterations within the microlayer (Ebling and Landing, 2017). Therefore, the SML is a potentially significant contributor to air-sea exchange processes affecting atmospherically delivered $\mathrm{Fe}$ and should be included in future modeling studies. However, modelers lack the necessary information to allow parameterization of ocean SML processes in global models. Future studies should aim at better characterizing the chemical composition and structure of organic matter found in the SML and explore the role of the SML in affecting the dissolution, speciation, and initial microbial interactions for atmospherically delivered DFe in the surface ocean. Organics in the SML could mobilize aerosol Fe from mineral dust through photochemical and heterogeneous reactions in the microlayer as well as chelate aerosol-derived DFe and lead to stable Fe-ligand complexes which are not prone to adsorption, aggregation and subsequent sinking. Fe mobilized from the oxides can then re-enter the Fe cycle through biotic reductive, organic ligand-promoted, and/or photoreductive dissolution (Schwertmann, 1991). Studies should also be carried out to better characterize the residence time of DFe and PFe delivered through atmospheric pathways and identify oceanic regions where the SML is expected to play important roles in Fe biogeochemistry (Ebling and Landing, 2017). Finally, SML-sourced material may become entrained in sea spray aerosols generated by bubble-bursting processes and could potentially serve as an oceanic source of DFe and PFe in marine aerosols.

\section{Atmospheric and oceanic organic ligands}

Organic ligands control the conversion of bioaccessible Fe to bioavailable $\mathrm{Fe}$ in seawater by chelation which protects DFe from scavenging onto sinking particles. Past ocean studies have mostly focused on strong " $\mathrm{L}_{1}$ " and weaker " $\mathrm{L}_{2}$ " ligands based on their conditional binding strengths. Ligand strengths are operationally defined by their stability constants, determined from voltammetric studies (Gledhill and Buck, 2012). Although ligands play a central role in the global biogeochemical cycling of Fe, the sources and sinks of ligands and the mechanisms involved in the cycling of ligands are still poorly quantified. There is some evidence for stronger ligands being present in deliquesced aerosol solution (Kieber et al., 2001; Kieber et al., 2005; Willey et al., 2008) and cloud/rainwater (Cheize et al., 2012; Vinatier et al., 2016). These ligands could contribute to the stabilization of aerosol DFe in seawater, though strong ligands in seawater are usually assumed to have an oceanic origin (Hunter and Boyd, 2007). Electrochemical titration studies, used for the operational definition of the ligand concentrations, show that strong ligand concentrations are typically low in the open ocean $(\sim 0.44 \mathrm{nM}$ or lower; concentrations of true siderophores as determined by LC-MS can even be at the 1 pM level, Mawji et al., 2008), though weaker ligand concentrations are slightly higher $(\sim 1.5 \mathrm{nM})$ (Gledhill and van den Berg, 1994; Rue and Bruland, 1995; Vraspir and Butler, 2009; Gledhill and Gerringa, 2017). Thus, atmospherically delivered DFe deposition events at the surface of the ocean can quickly deplete the number of available "excess" $L_{1}$ and $L_{2}$ ligands. Therefore, part of the discussion was focused on improved understanding of "super-weak" ligands (e.g., $\mathrm{L}_{3}$ and $\mathrm{L}_{4}$ ligands, with conditional stability constants $\log \mathrm{K}_{\mathrm{Fe}^{\prime} \mathrm{L}}{ }^{\text {cond }}<11$, see Gledhill and Buck, 2012) of both atmospheric and marine origin (Bundy et al., 2015). Increasing evidence shows that super-weak ligands like hydroxy-polyacids, polysaccharides, and humic-like substances play a role in oceanic Fe complexation (Laglera and van den Berg, 2009; Laglera et al., 2011; Hassler et al., 2011a, 2011b). Besides being a component of the bulk dissolved organic matter in seawater, such organics are commonly found at high concentrations $(\sim \mu \mathrm{M})$ in aerosols (Kawamura, 1993; Röhrl and Lammel, 2002; Graham, 2002; Willey et al., 2008; Fu et al., 2011; Paris and Desboeufs, 2013; Gantt and Meskhidze, 2013), cloud/rainwater (Cheize et al., 2012; Vinatier et al., 2016), and the SML (Henrichs and Williams, 1985; Kuznetsova and Lee, 2002; Aller et al., 2005; Hawkins and Russell, 2010; Cunliffe et al., 2013) over different parts of the oceans and coastal regions. These organics are either directly emitted to the atmosphere by fossil fuel combustion and biomass burning or produced in the atmosphere by secondary photochemical oxidations of anthropogenic and natural volatile organic compounds (VOC) (Goldstein and Galbally, 2007, Al-Abadleh, 2015. Moreover, it was suggested that the presence of a dimethylsulfide (DMS) oxidation products (e.g., sulfur dioxide $\left(\mathrm{SO}_{2}\right)$, sulfuric acid $\left(\mathrm{H}_{2} \mathrm{SO}_{4}\right)$, and methanesulfinic acid $\left(\mathrm{CH}_{3} \mathrm{SO}_{2} \mathrm{H}\right)$ ), can increase release of soluble $\mathrm{Fe}(\mathrm{II})$ in atmospheric aerosols, providing an efficient mechanism by which phytoplankton can actively enhance the dissolution of iron within acidic aerosol particles in the marine atmosphere (Zhuang et al., 1992; Johansen and Key, 2006). Super-weak organic ligands could chelate atmospherically delivered DFe in the aqueous aerosol phase and form complexes which prevent aggregation and/or adsorption onto larger than $0.45 \mu \mathrm{m}$ sized particles. By extending the lifetime of DFe in seawater from hours to days, these super-weak organic ligands allow sufficient time for $\mathrm{L}_{1}$ or $\mathrm{L}_{2}$ ligands to be replenished in the dust-affected region through vertical mixing or biological production and release, considerably increasing the probability of DFe in the ocean encountering $\mathrm{L}_{1}$ or $\mathrm{L}_{2}$ ligands (Croot and Heller, 2012; Meskhidze et al., 2017). Understanding the kinetics of how this heterogeneous mix of compounds with different binding strength complexes atmospherically delivered DFe, and how this is affected by other factors, such as $\mathrm{pH}$ (Avendaño et al., 2016) will be important to constrain in future studies.

\section{A conceptual model for the roles of particle size, residence time, and speciation}

Particle size distribution can have a significant effect on the amount of bioaccessible Fe in atmospheric aerosols. Aerosol size can have a direct effect on the chemical composition of Fe containing minerals (Claquin et al., 1999; Nickovic et al., 2013; Shi et al., 2009). Particle size also has an indirect effect on DFe content through chemical processing (e.g., Zhu et al., 1992; Spokes and Jickells, 1996; Meskhidze et al., 2003, 2005; Ito and Feng, 2010; Johnson and Meskhidze, 2013) and, to lesser extent, through physical size sorting during the atmospheric transport (Shi et al., 2011a, 2011b, 2011c). Despite its importance, in situ measurements report a wide range in mineral aerosol 
size distribution (see Fig. 1 in Meskhidze et al., 2016). Such variability in size can lead to significant differences in atmospheric model-predicted concentrations of aerosol DFe and subsequent fluxes of bioaccessible Fe to the oceans (Meskhidze et al., 2016). Moreover, wetting of mineral dust particles through rainout or washout, or even during the leaching of the dust-laden filters can cause changes in particle physical size distribution through the breakage of dust grains and dissolution of salts (Dudhaiya and Santos, 2018). As a result of such changes, Fecontaining nanoparticles (particles $<0.1 \mu \mathrm{m}$ in diameter) attached to the dust particles can be released into solution, thereby increasing DFe concentration. The opposite could happen when DFe in aerosol/rainwater solution gets deposited to the surface ocean. In such a case, DFe can aggregate and form nano- to micron-sized (oxyhydr)oxide (FeOOH) particles, leading to a decrease in DFe concentration. Although several theoretical models (e.g., classical Derjaguin-Landau-Verwey-Overbeek theory of colloidal behavior, Derjaguin et al., 1987; Verwey, 1947) have been proposed in colloid science to describe cluster formation as colloids possessing "sticky hard sphere" characteristics, colloids that interact only through short-range repulsive interaction, and for colloids possessing significant long-range repulsive interactions, presently there is a poor understanding of phase changes for mineral particles and its effect on DFe. These processes are further complicated by the presence/ absence of atmospheric and oceanic organic ligands. Today it is clear that aerosols should not be treated as single particles (with either surrounding aqueous phase or submerged in raindrops), but as more dynamic and complex organic-inorganic aggregates. Such aggregates can both increase or decrease the DFe concentration in surface ocean water depending on (i) concentrations and complexing capacities of strong ligands that help set the solubility limit for Fe (Wagener et al., 2008; Ye et al., 2011; Fishwick et al., 2014; Chien et al., 2016), (ii) concentration of the weaker and super-weaker ligands that affect the cycling between soluble, colloidal, and particulate phases of Fe (e.g., Willey et al., 2008), (iii) photochemistry, driven by the production of superoxide through interaction of light with colored dissolved organic matter, or organic ligands (e.g., Voelker and Sedlak, 1995; Croot et al., 2008), (iv) the presence of SML components that may increase accumulation of aerosols at the ocean surface, such as adhesion to the polysaccharidic gelatinous phase (e.g., Wurl et al., 2017), (v) interaction with bacteria such as Trichodesmium colonies that can retain mineral dust and actively promote Fe mobilization (Rubin et al., 2011; Basu and Shaked, 2018), and (vi) the size distribution of deposited particles because of aggregation of small particles to faster sinking larger particles (Ternon et al., 2010; Bressac et al., 2012, 2014; Ohnemus and Lam, 2015; Louis et al., 2017). It is well understood that these processes are crucial for an accurate representation of both the changes in the particle size distribution in the mixed layer and the residence times of mineral dust particles in the surface ocean. However, not all of the studies mentioned above have attempted to describe the processes mechanistically in the form of rate laws. Further laboratory measurements should, therefore, be carried out to elucidate atmospheric particle size changes as a result of both dry and wet deposition of particles, in the presence and absence of the SML. Furthermore, such studies should be carried out in seawater with varying bacterial abundance as well as DFe, colloidal particles, and ligand concentrations. Laboratory and field studies have demonstrated the crucial role played by the dissolved organic matter pool in the aerosol post-depositional processes (i.e., bioaccessibility, scavenging, and aggregation of DFe, Wagener et al., 2008, 2010; Wuttig et al., 2013; Bressac and Guieu, 2013). Detailed modeling studies are also needed to test the sensitivity of the system to key processes affecting residence time and speciation of aerosol $\mathrm{Fe}$ after deposition to the ocean. Such laboratory studies and model simulations should lead to a process-level understanding of atmospheric aerosol Fe biogeochemistry in the ocean at different spatiotemporal scales and help identify key processes that will improve the predictive power of ESMs.
10. Using other trace elements for improved understanding of Fe biogeochemistry

Lithogenic Fe and other dust-derived elements have similar delivery pathways to the ocean. However, several trace metals are characterized by unique biogeochemical cycling patterns in the surface ocean. Therefore, multiple trace metals can be used to constrain the inputs of Fe. Leveraging measurements of a set of trace elements to create additional holistic understanding is at the heart of the GEOTRACES science plan (www.geotraces.org/science/science-plan). There are several elements that share some-but not all—of the Fe cycling mechanisms, potentially allowing us to disentangle some of the compensating mechanisms (sources and sinks). Aluminum (Al) has traditionally been used to estimate Fe input (Measures and Vink, 2000). Aluminum (and titanium, Ti) has a predominantly crustal origin in seawater, and has no known biological function, meaning that its dissolved concentration is not strongly affected by biological activity. Resuspension of particles in nepheloid layers and along coastal shelves (Puig et al., 2008; Durrieu de Madron et al., 2017) is also a source that can be indistinguishable from aerosols in some locations. $\mathrm{Al}$ and $\mathrm{Fe}$ have similar (and variable) fractional solubilities, while that of Ti is significantly lower. Both dissolved $\mathrm{Al}$ and $\mathrm{Ti}$ have a longer residence time in seawater (with respect to scavenging) than Fe and can be used as a measure of integrated Fe input into the ocean over seasonal timescales (Dammshäuser and Croot, 2012). On the contrary, the distribution of DFe with its shorter residence time often correlates with particulate forms of $\mathrm{Al}$ from recent dust deposition events (Jickells, 1999; Schüßler et al., 2005). Particulate $\mathrm{Al}$ and particulate $\mathrm{Ti}$ can also be used to estimate lithogenic particle mass and seem less affected by scavenging of $\mathrm{Al}$ and Ti from the dissolved phase. Another advantage of using $\mathrm{Al}$ is that its distribution and cycling has been implemented in an ocean general circulation model (van Hulten et al., 2013). Thorium isotopes could also be used to quantify scavenging onto particles and re-dissolution rates (Wang et al., 2016).

Other elements, such as vanadium (V), chromium (Cr), manganese $(\mathrm{Mn})$, and lead $(\mathrm{Pb})$ are enriched in anthropogenic aerosols from power plants or biomass burning and thus can be used to relate changes in $\mathrm{Fe}$ solubility to aerosol composition (Herut et al., 2016). The cycling of Mn shares many of the complexities of Fe cycling (biological function, more than one redox state, organic complexation), and is also delivered mostly by dust to open-ocean waters. Its fractional solubility also seems to be strongly affected by the aerosol source (Buck et al., 2013). Other trace metals from mineral dust, such as gallium (Ga) or thorium (Th), can also be used to derive indirect estimates of dust deposition using the dissolved distribution of these metals in seawater (Baker et al., 2016).

\section{Regional and global modeling}

\subsection{Oceanic models}

Ocean Fe biogeochemical models are still highly simplistic and generic in their description of Fe input from aerosol deposition, and in the role of Fe speciation in it, especially when compared to the level of detail now found in atmospheric chemistry models. Most ocean models still assume a constant weight fraction of $\mathrm{Fe}$ in mineral dust and a constant dissolved Fe fraction in aerosols (Parekh et al., 2004; Dunne et al., 2013; Aumont et al., 2015) but a prescribed variable solubility is becoming applied as well (Albani et al., 2016Ito et al., 2019). Photochemistry has only been modeled in a few regional studies (Weber et al., 2005; Ye et al., 2009), or in a simplified manner globally (Tagliabue and Völker, 2011). The properties of organic ligands for Fe in the ocean are less well constrained than for Fe in the aerosols. Most models use a fixed concentration of one generic Fe-binding ligand (Tagliabue et al., 2016) and only a few models describe the spatiotemporal variability of ligands either prognostically (Völker and Tagliabue, 2015) or through diagnostic relations to apparent oxygen 
utilization and dissolved organic carbon (Misumi et al., 2013).

For a better description of the bioaccessible Fe input into the ocean from aerosol deposition in future modeling studies, it will be prudent to investigate the roles of (i) colloidal/nanoparticulate Fe vs. that of DFe; (ii) photochemically produced Fe(II) and the photochemical breakdown of ligands; (iii) the conversion of bioaccessible Fe into bioavailable $\mathrm{Fe}$ within the SML; and (iv) super-weak ligands (e.g., $\mathrm{L}_{3}$ and $\mathrm{L}_{4}$ ), such as organic ligands deposited with atmospheric particles, and ligands in the SML and the upper ocean such as humic acids, and polysaccharides (Bundy et al., 2015) and (v) the timescales and variable/reversible scavenging rates of DFe (Tagliabue et al., 2016). To gain some understanding of the possible roles and sensitivities for several of these processes, a useful strategy could be one-dimensional modeling of lesswell-known processes prior to inclusion into global biogeochemical models.

Many of the suggested areas for improvement of ocean modeling require kinetic information from carefully designed and implemented laboratory studies that can yield a methodological description of individual processes. The experimental community can improve the mathematical formalism of future publications by including the descriptive equations of the mechanisms being studied. The biogeosciences literature is often lacking in mathematical formalism leading to misinterpretation, miscommunication, and confusion. By explicitly describing the assumed mathematical equations of specific biogeochemical mechanisms in future publications, authors will improve reproducibility and testability. In turn, modelers can use the data from experimentalists as intended and experimentalists can see how modelers use their data. To give an example: Iron biogeochemical models often describe the scavenging loss of DFe as the product of the inorganic fraction of dissolved iron concentration (encompassing the inorganic forms of both $\mathrm{Fe}(\mathrm{II})$ and $\mathrm{Fe}(\mathrm{III})$ ), multiplied by a concentration of the scavenging phase (e.g., organic detritus) in mass units (i.e., mass per volume), and a specific scavenging rate (Tagliabue et al., 2016). Experimentalists might find it more reasonable to use the particle surface area instead of its mass when describing scavenging in an experiment. For modelers, it would then be extremely helpful to have some indication of the specific surface processes for the scavenging phase.

\subsection{Atmospheric models}

Mineral dust and other Fe-containing particles are injected in the atmosphere at the source regions (desert soils, biomass burning, anthropogenic). Models prescribe size distribution and mineralogy (for aeolian dust) and various initial Fe solubilities (for different combustion sectors) at the source regions. Iron solubility is typically defined as the ratio of DFe over total $\mathrm{Fe}$. $\mathrm{Fe}$ in atmospheric mineral dust is primarily in the form of Fe-(oxyhydr)oxides, such as hematite $\left(\alpha-\mathrm{Fe}_{2} \mathrm{O}_{3}\right)$, goethite $(\alpha-\mathrm{FeO}(\mathrm{OH}))$, and ferrihydrite $\left(\mathrm{Fe}_{2} \mathrm{O}_{3} \cdot 0.5 \mathrm{H}_{2} \mathrm{O}\right)$ and as ferric iron $(\mathrm{Fe}$ (III)) substituted into aluminosilicate clay minerals (Dedik et al., 1992; Hoffmann et al., 1996; Arimoto et al., 2002). In addition to Fe-containing minerals, atmospheric models now prescribe detailed mineralogy of wind-blown dust from the major desert regions. Mineralogical composition has been shown to play a critical role in atmospheric transport and transformation of mineral dust particles (Meskhidze et al., 2005; Solmon et al., 2009; Journet et al., 2008; Johnson and Meskhidze, 2013; Perlwitz et al., 2015; Scanza et al., 2015; Raiswell et al., 2017). The average Fe content of $3.5 \%$ is typically prescribed for mineral dust (e.g., Duce et al., 1991), though it has been shown that this value can vary considerably in upper crustal minerals depending on the underlying mineralogy (and geography) of the dust source (Journet et al., 2014; Nickovic et al., 2013). To characterize so-called readily released Fe (Mackie et al., 2006) associated with ultra-fine, poorly crystalline Fe (oxyhydr)oxides (Shi et al., 2011a, 2011b, 2011c) produced through sand-blasting (the dominant process in producing fine dust aerosols during saltation Gillette, 1978; Kok, 2011), atmospheric models prescribe an initial dust Fe solubility between 0.1 and $0.45 \%$ (Myriokefalitakis et al., 2018). The variable (4.3\% on kaolinite and 3\% on feldspars) initial solubility of the emitted Fe-containing dust particles has also been used (Ito and $\mathrm{Xu}, 2014$ ). The initial Fe solubility for combustion aerosols ranges from 4 to $80 \%$ (Myriokefalitakis et al., 2018). The majority of Fe mass found in the atmosphere is contained within mineral dust aerosols emitted from continental sources. However, due to their spatiotemporal distribution and higher Fe solubility, aerosols originated from wildfires and biomass burning (Guieu et al., 2005; Oakes et al., 2012; Paris et al., 2010) and anthropogenic combustion processes, such as coal and oil fly ash (Chung et al., 2005; Chen et al., 2006; Sedwick et al., 2007; Luo et al., 2008), including ship oil combustion (Ito, 2013) have also been included in atmospheric models (Matsui et al., 2018; Ito et al., 2019a). During atmospheric transport, coating of Fe-containing dust particles by acidic compounds (e.g., sulfur and nitrogen, compounds) and organic species (e.g., DOC) increases the hygroscopicity of dust particles, allowing them to be engaged in complex physical and photo(chemical) interactions (Duce and Tindale, 1991; Zhuang et al., 1992; Meskhidze et al., 2003, 2005). The resulting solid-, aqueous-, and gas-phase reactions make aerosols more acidic and increase Fe mobilization (Johnson and Meskhidze, 2013; Ito and Shi, 2016). Atmospheric Fe biogeochemistry models now routinely consider the three main mechanisms of Fe dissolution from atmospheric aerosol (i.e., proton-promoted, organic ligand-promoted, and photoreductive) with photochemical redox cycling between $\mathrm{Fe}(\mathrm{III})$ and $\mathrm{Fe}(\mathrm{II})$ (Myriokefalitakis et al., 2018).

However, some potentially important processes are currently missing from atmospheric models. Future models should include atmospheric organic ligands, incorporate some novel pathway initiated by gaseous uptake of hydroperoxyl radical $\left(\mathrm{HO}_{2}\right)$ and followed by $\mathrm{Cu}-$ Fe redox coupling (Mao et al., 2013), account for new pathways for efficient formation of secondary organic polymeric particles catalyzed by $\mathrm{Fe}$, and better represent larger ( $>10 \mu \mathrm{m}$ in diameter) dust particles. These suggestions are based on some of the recent studies that have shown that atmospheric DOC species are capable of extending the lifetime of atmospherically delivered DFe in the ocean (Meskhidze et al., 2017). The $\mathrm{Cu}-\mathrm{Fe}$ redox coupling that has been incorporated in aqueous aerosol and cloud chemistry models (Herrmann et al., 2000) should be reevaluated as a mechanism to sustain nighttime Fe(II) and dominate $\mathrm{Fe}(\mathrm{III})$ reduction in the absence of $\mathrm{Fe}(\mathrm{III})$-organic complexes (Mao et al., 2017). Recent studies have also shown that oxidative polymerization of polyphenols and metal-catalyzed polymerization of dicarboxylic acid could be important sources of Fe-complexing atmospheric organic ligands (Slikboer et al., 2015; Tran et al., 2017). Finally, "giant" sand-sized ( $>63 \mu \mathrm{m}$ in diameter) particles, often found thousands of kilometers away from the source (Stuut and Prins, 2014; van der Does et al., 2018), could influence Fe biogeochemistry by both increasing atmospheric fluxes of $\mathrm{Fe}$ and scavenging of DFe from the surface ocean. Other sources of Fe from atmospheric aerosols which are attributed to volcanic eruptions (van der Does et al., 2018); (Duggen et al., 2010; Langmann et al., 2010; Lindenthal et al., 2013) and to a lesser extent meteors (Johnson, 2001) have also been identified, but are not included in current atmospheric models.

Currently, there are two different approaches to parameterize $\mathrm{Fe}$ dissolution rates. In a top-down approach, Fe dissolution rates for $\mathrm{Fe}$ containing aerosols used in the models are tuned with the data from field measurements. As most of the field measurements are carried out in the Northern Hemisphere, such studies often lead to an overestimate of aerosol Fe solubility in the Southern Hemisphere. In a bottom-up approach, Fe dissolution rates for Fe-containing aerosols are fit to the data from laboratory experiments, often using mineral dust samples from arid regions. Such studies generally lead to an underestimate of aerosol $\mathrm{Fe}$ solubility in both the Northern and the Southern Hemispheres. In the Northern Hemisphere, high Fe solubility at low concentration can be reproduced by mixing the mineral dust with combustion aerosols of higher Fe solubility (Ito, 2013). Today the vast 
majority of ambient data that can be used for model comparison of aerosol Fe comes from research cruise measurements (see Fig. 6 in Wang et al., 2015). While cruise measurements significantly help advance our understanding of Fe biogeochemistry (both in the atmosphere and in the ocean), they provide limited information on the spatiotemporal distribution of bioaccessible Fe in atmospheric aerosols.

All participants agreed that detailed long-term in situ measurements that can monitor both atmosphere and ocean properties are also necessary. Long-term observations that can link atmospheric material transport and marine biogeochemistry would facilitate both communications between groups working in different areas and development of universal parameterizations for implementation in numerical models (Brévière et al., 2015). The temporal resolution of sampling at the sites should be sufficient to resolve variability in both atmospheric deposition and ecosystem responses. In such case, the time series sites could become focal points for detailed in-depth experiments and process-level studies that can address wet and dry deposition processes, cycling of different Fe phases within the SML and the photic zone, and the kinetics for aerosol-derived bioaccessible Fe transformation into bioavailable/ colloidal/particulate forms in seawater. Participants agreed that the priority could be given to a few island sites, where long-term records from island sampling sites exist (e.g., Bermuda, Barbados, Miami). However, building new stations that monitor both atmosphere and ocean properties is also necessary. New long-term observing programs should be promoted downwind from dust source areas in the Southern Hemisphere (South America, Australia, South Africa), where observations are very sparse, and the ocean ecosystem is expected to be most sensitive to Fe inputs. For future locations of long term in situ measurements, we follow the recommendations of the Group of Experts on Scientific Aspects of Marine Environmental Protection (GESAMP) Working Group 38 (Duce and Liss, 2011). Stations in the North Atlantic (e.g., Barbados, Bermuda, Miami, Izaña, French Guiana, Iceland) will play an important role by making measurements of aerosols and deposition which will serve as the critical test-bed data for the further development of dust transport models. The station in the Falkland (or Las Malvinas) Islands could be ideal for measuring Fe transport from the sources in southern South America (Gassó and Stein, 2007; Johnson et al., 2011), which is believed to be one of the major sources of aerosol Fe to the Southern Oceans. Due to difficult logistics and little dust, there are not too many other good options in the Southern Ocean. Nevertheless, the Cape Grim Baseline Air Pollution Station, located in remote northwestern Tasmania, Reunion Island, Marion Island, and Prince Edward could also be considered. In the North Pacific, Midway island is ideally situated to monitor the transport of mineral dust and anthropogenic sources of Fe from the Asian continent. Norfolk and Chatham Islands in South Pacific are well suited to monitor Australian sources, that are believed to be the major source of dust for the South Pacific and the Southern Ocean. The Maldive Islands in the Indian Ocean receives great quantities of dust and pollution largely transported from the Indian subcontinent during the Northeast Monsoon.

One way to evaluate the skill of atmospheric models has been to test their ability to reproduce the observed log-log plots of the dissolved Fe fraction $\left(\% \mathrm{DFe}=\mathrm{DFe} / \mathrm{Fe}_{\mathrm{T}} \times 100\right)$ versus total $\mathrm{Fe}\left(\mathrm{Fe}_{\mathrm{T}}\right)$ loading. The linear dependency detected for individual datasets plotted as the log$\log$ plots is often interpreted as a combination of two endmembers corresponding to a low iron solubility (for Fe from mineral dust) and a high solubility (for Fe from combustion). It is generally accepted that the linear dependence (on the log-log plots) holds despite using i) a range of different leaching techniques, ii) types of Fe extraction solutions, iii) $\mathrm{pH}$ values of the solution, iv) extraction times, v) (photo) reductant agents, vi) operational definitions for fractional solubility of $\mathrm{Fe}$ in mineral dust, and vii) Fe measuring instruments. However, the linear dependency in the log-log space may also be an artifact of plotting two variables against each other that are not independent. Expressed as a function of $\mathrm{Fe}_{\mathrm{T}}, \% \mathrm{DFe}$ is inversely related to $\mathrm{Fe}_{\mathrm{T}}$. This forces an asymptotic curve in linear space and a linear dependency in log-log space. To visualize this artifact, 1000 random numbers were chosen between 0 and 100 for $\mathrm{Fe}_{\mathrm{T}}$ and between 0 and 3 for DFe, while not allowing for numbers of $\mathrm{DFe}>\mathrm{Fe}_{\mathrm{T}}$. The $\mathrm{DFe}$ and $\% \mathrm{DFe}$ was calculated and plotted vs. $\mathrm{Fe}_{\mathrm{T}}$ in Figs. $1 \mathrm{a}, \mathrm{b}$ and $\log (\% \mathrm{DFe})$ was plotted vs. $\log \left(\mathrm{Fe}_{\mathrm{T}}\right)$ in Fig. 1c. An analogous web-based animated figure (https:// zzqvaay3twhzlhnmvpvdvq-on.drv.tw/Web/Fe_Function.html) allows (a)

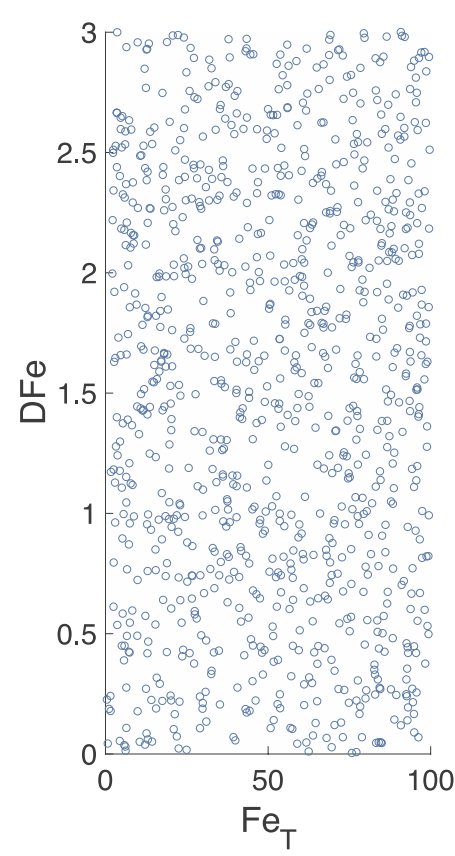

(b)

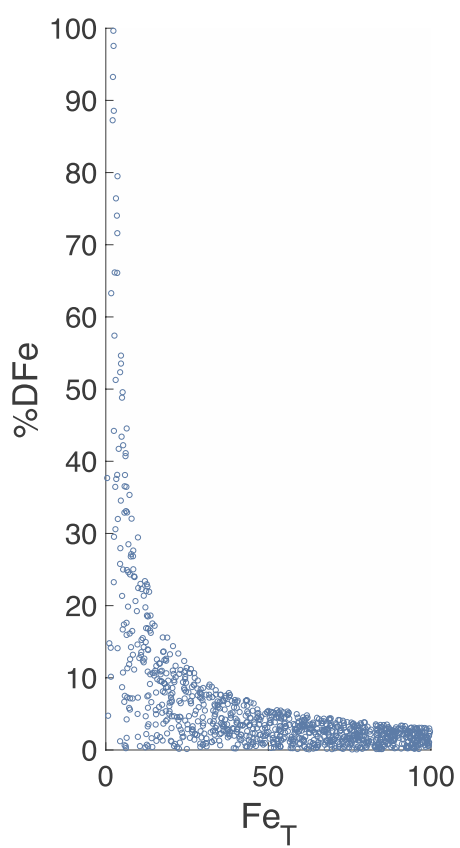

(c)

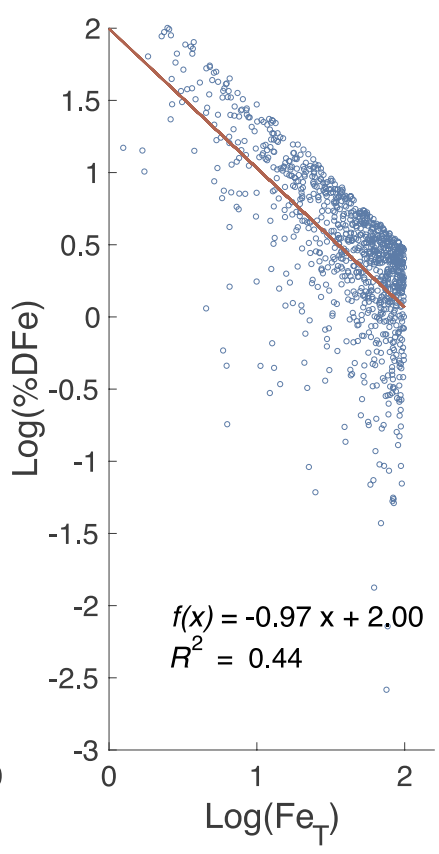

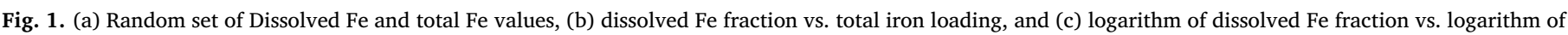

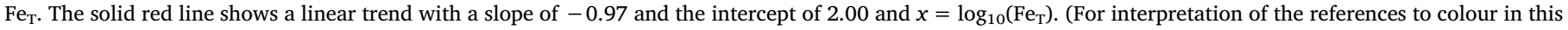
figure legend, the reader is referred to the web version of this article.) 
custom changes in both $\mathrm{DFe}$ and $\mathrm{Fe}_{\mathrm{T}}$ that are displayed in three plots: $\mathrm{DFe}$ vs. $\mathrm{Fe}_{\mathrm{T}}$ (showing the randomness), \%DFe vs. $\mathrm{Fe}_{\mathrm{T}}$ (showing the asymptotic relationship), and $\log (\% \mathrm{DFe})$ vs. $\log \left(\mathrm{Fe}_{\mathrm{T}}\right)$ (showing the linear relationship). The asymptotic nature of the \%DFe vs. $\mathrm{Fe}_{\mathrm{T}}$ and the linear dependency of the log-log plots are thus generated regardless of the data that is randomly chosen. Furthermore, the linear curve in the log-log plot has a slope of close to -1 as is expected when taking the logarithm of an inverse function. These values are somewhat different from $\log (\% \mathrm{DFe})$ vs. $\log \left(\mathrm{Fe}_{\mathrm{T}}\right)$ relationship reported by Myriokefalitakis et al. (2018) $\left(-0.34,1.10\right.$, and 0.30 for the slope, intercept, and $\mathrm{R}^{2}$ value, respectively). Nevertheless Fig. 1 suggests that the interpretation of the $\% \mathrm{DFe}$ vs. $\mathrm{Fe}_{\mathrm{T}}$ relationship as a combination of two endmember aerosol types should be accompanied by other parameters that can be used to evaluate the contribution from combustion aerosols (e.g., Srinivas et al., 2012), mapping organic coatings and characterization of single-particle oxidation state of Fe-containing atmospheric particles (e.g., Takahama et al., 2008) or characterization of atmospheric aging and chemical weathering of mineral dust (e.g., Shi et al., 2011a, 2011b, 2011c).

\section{Prioritization matrix}

Table 3 shows a science prioritization matrix of a number of $\mathrm{Fe}-$ biogeochemistry research areas from four broad categories: Atmospheric Model Representation, Ocean Model Representation, Atmospheric Measurement Methodologies, and Ocean Measurement Methodologies. On the modeling side, a number of topics with the lowest level of understanding and the highest impact if achieved include parameterization of bulk aerosol deposition fluxes (both wet and dry), aerosol size-resolved mineralogy, $\mathrm{Fe}(\mathrm{II}) / \mathrm{Fe}(\mathrm{III})$ partitioning and photochemical cycling, and distribution/characterization of Fe complexing organic ligands. On the measurement side, they are: a characterization of individual particle acidity, Fe(II) content, and the bioavailable fraction of aerosol Fe. Nearly all of these topics affect the residence time and concentration of DFe in the ocean, are related to the atmospheric fluxes of aerosols, and $\mathrm{Fe}(\mathrm{II}) / \mathrm{Fe}(\mathrm{III})$ interaction with organic ligands both in the atmosphere and seawater.
Within the Atmospheric Model Representation category, topics pertaining to size-resolved properties were mostly classified as having a lower level of understanding and higher impact if achieved compared to bulk aerosol properties. Topics such as aerosol size-resolved $\mathrm{Fe}(\mathrm{II}) / \mathrm{Fe}$ (III) partitioning and Fe-complexing organic ligands in the atmosphere were ranked at a low level of understanding but were assigned high impact if achieved. Most of the topics in the Ocean Model Representation category were evaluated as low understanding but at a medium or high impact if achieved because of their importance in determining the surface concentration and residence time of DFe. Several topics in Atmospheric and Oceanic Measurement Methodologies had low levels of understanding because of the difficulty in making ambient measurements and/or relating laboratory results to the ambient environment, i.e., aerosol acidity, bioavailable $\mathrm{Fe}$, Fe speciation in the ocean and kinetic measurements (e.g., ligand degradation and scavenging).

Nine topics were identified as high difficulty and/or high cost, and eight of these were also ranked as low understanding and high impact if achieved: Aerosol size-resolved Fe(II)/Fe(III) partitioning, wet/dry removal of aerosols, Fe complexing organic ligands, surface microlayer and its chemical composition, aerosol acidity, bioavailable Fe, Fe speciation within the particulate and dissolved phases, and kinetic measurements of ligand transformations in seawater. Broadly, these are the areas where concerted efforts such as large-scale field campaigns and joint multidisciplinary laboratory studies could lead to more cost-effective ways to collectively address these topics. Nine topics, such as aerosol bulk mass fluxes, giant aerosol particles, aerosol bulk $\mathrm{Fe}(\mathrm{II}) / \mathrm{Fe}$ (III) partitioning, atmospheric processing of aerosol, Fe complexing organic ligands, size/phase-resolved residence time, vertical distribution of $\mathrm{Fe}$, and $\mathrm{DFe}(\mathrm{II})$ were ranked as low-med scientific understanding, high impact if achieved, and medium difficulty, and thus are worth targeting in the near future.

\section{Conclusions and suggestions for future work}

Improved understanding of processes controlling Fe speciation and residence time at the atmosphere-ocean interface requires additional

Table 3

Science Prioritization Matrix

\begin{tabular}{|c|c|c|c|}
\hline Parameter & Current understanding & Impact if achieved & Difficulty/resources needed \\
\hline \multicolumn{4}{|l|}{ Atmospheric model representation } \\
\hline Aerosol bulk mass concentration & Med & High & Med \\
\hline Aerosol bulk mass fluxes & Low & High & Med \\
\hline Aerosol particle size distribution in the marine boundary layer & Med & High & Med \\
\hline Giant aerosol particles & Low & High & Med \\
\hline Aerosol bulk mineralogy/phase & Med & Med & Med \\
\hline Aerosol size-resolved mineralogy/phase & Med & High & High \\
\hline Aerosol bulk Fe(II)/Fe(III) partitioning & Low-Med & High & Med \\
\hline Aerosol size-resolved $\mathrm{Fe}(\mathrm{II}) / \mathrm{Fe}(\mathrm{III})$ partitioning & Low & High & High \\
\hline Atmospheric processing of aerosol & Low-Med & High & Med \\
\hline Wet/dry removal of aerosols & Low & High & High \\
\hline Fe complexing organic ligands & Low & High & Med \\
\hline \multicolumn{4}{|l|}{ Ocean model representation } \\
\hline Surface microlayer and its chemical composition & Low & Med-High & High \\
\hline $\mathrm{Fe}(\mathrm{II}) / \mathrm{Fe}(\mathrm{III})$ photochemical cycling & Low & High & Med-High \\
\hline $\mathrm{Fe}(\mathrm{II})$ ligand distribution (if any) & Low & Low-Med & Med \\
\hline Fe(III) ligand distribution & Med & High & High \\
\hline Size/phase-resolved residence time and vertical distribution of $\mathrm{Fe}$ & Low-Med & High & Med \\
\hline Size/phase-resolved particle flux & Low-Med & High & Med \\
\hline \multicolumn{4}{|l|}{ Atmospheric measurement methodologies } \\
\hline Ambient aerosol collection coupled with the gas phase measurement & Low & Med & Med \\
\hline Aerosol acidity & Low & High & High \\
\hline $\mathrm{DFe}(\mathrm{II})$ & Low & High & Med \\
\hline Operationally defined DFe(III) & Med & High & Med \\
\hline Bioavailable $\mathrm{Fe}$ & Low & High & High \\
\hline \multicolumn{4}{|l|}{ Ocean measurement methodologies } \\
\hline Fe speciation from particles to truly dissolved & Low & High & High \\
\hline Kinetic measurements (ligand degradation, scavenging) & Low & High & High \\
\hline
\end{tabular}


laboratory studies, field measurements, and modeling research. Several specific ideas are summarized below:

\subsection{Laboratory experiments and in situ field measurements}

Laboratory studies are needed on model systems containing Fechelating organic compounds found in both the atmosphere and ocean, while field measurements are crucial for understanding the in-situ transformations of Fe resulting from aerosol deposition to the surface ocean. New studies need to be conducted on natural and anthropogenic aerosols of variable size distribution, chemical composition, and mineralogy. The experiments should be carried out at different temperature, relative humidity, acidity, and concentrations of organic compounds to mimic atmospheric photo(chemical) reactions occurring in the bulk phase and the surface of the particles. Future laboratory and field measurements should focus on:

- Standardizing Fe measurement methodologies for both aerosols and seawater.

- Developing a mechanistic understanding of issues related to bioavailability of different forms of $\mathrm{Fe}$ found in the atmosphere and in the ocean.

- Improving characterization of aerosol water content and acidity and their collective impact on Fe dissolution.

- Examining atmospheric and oceanic weak ligands such as dicarboxylic acids, hydroxy-polyacids, polysaccharides, and humiclike substances and their role in Fe complexation in the ocean.

- Using large, trace-metal-clean mesocosms to investigate dust-related processes in the surface ocean.

- Studying the role of the SML for both mobilization of total aerosol Fe to DFe and the transformation of bioaccessible Fe into bioavailable DFe in seawater.

- Analyzing the scavenging of aerosol Fe after deposition to seawater and examining the phase changes (from dissolved to (oxy)hydroxides) during Fe precipitation in seawater with variable particulate matter and DFe concentrations.

- Analyzing the morphology, size, mineralogy, and Fe oxidation state of individual aerosol particles in the samples collected in multiple locations over the oceans using a combination of synchrotron total reflection X-ray fluorescence (SR-TXRF) and the angle-dependent measurements and/or X-ray absorption near-edge structure (XANES) spectroscopy.

- Chemical and biochemical analysis of ocean SML and rainwater samples using standard test dust and real aerosol samples for understanding the Fe-complexing potential of key organic ligands. Studies that use genetically tractable model marine bacteria strains for probing bioavailability of microlayer/Fe solutions would be particularly useful.

- In-situ speciation of Fe(II) and Fe(III) in seawater, including the physical speciation (particulate, colloidal, and dissolved) as well as the chemical speciation (e.g., inorganic Fe, ligand-bound $\mathrm{Fe}$, and nano-particulate $\mathrm{Fe}$ ). Special attention should be paid to the organically bound $\mathrm{Fe}$ fraction in seawater, as organic molecules can greatly affect the bioaccessible forms of $\mathrm{Fe}$ in atmospheric aerosols. Studies that characterize the Fe-binding ligands using a combination of voltammetry techniques and liquid-chromatography coupled to mass spectrometry will be particularly helpful in advancing our knowledge of organic Fe-binding ligands both in deliquesced aerosols and seawater. How these compounds are partitioned into the truly dissolved and colloidal phases will also shed additional insight into the physicochemical speciation of Fe.

- Studying the kinetics of aerosol-derived bioaccessible Fe transformation into bioavailable/colloidal/particulate forms of $\mathrm{Fe}$ in seawater to elucidate the role of in-situ speciation on the Fe biogeochemistry. These measurements will likely involve the integration of knowledge, methods, and expertise in atmospheric chemistry, dust/aerosol geochemistry, organometallic geochemistry, photochemistry, aquatic geochemistry, molecular biology, and chemical and biological oceanography.

\subsection{Models}

Global 3-D chemistry-transport (CTMs) and general circulation (GCMs) models predict the mean global atmospheric deposition fluxes

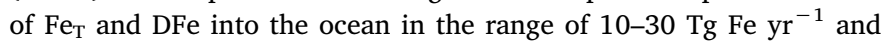
0.2-0.4 $\mathrm{Tg} \mathrm{Fe} \mathrm{yr}^{-1}$, respectively (Myriokefalitakis et al., 2018). The global ocean biogeochemical models use atmospheric fluxes of DFe in a

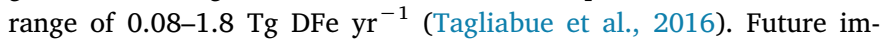
provements to model representation of Fe biogeochemistry should include:

- Fe speciation/phases for DFe (Fe(II) and Fe(III)) for atmospheric and (PFe, DFe, CFe) in the oceanic models.

- A more clearly defined and detailed Fe deposition and dissolution mechanism (along with the nomenclature).

- Detailed kinetics of aerosol bioaccessible Fe transformation into bioavailable/colloidal/ particulate forms of $\mathrm{Fe}$ in seawater.

- The details of reversible scavenging: Formulation of the adsorption/ desorption rates (0th order, 1st order, or 2nd order kinetics), particle types, sizes, and sinking speeds.

- Inclusion of other (e.g., $\mathrm{Cu}, \mathrm{Al}$, etc.) trace elements in addition to $\mathrm{Fe}$.

- Ligand modeling and ligand-Fe complex formation with the impact on bioavailability.

- Model accessibility (e.g., A Working Environment for Simulating Ocean Movement and Elemental Cycling (AWESOME OCIM) initiative, http://www.mtel.rocks/mtel/awesomeOCIM.html), which is focused on global distributions and long time-scales. This concept could be amended for short time-scales and specific experiments by a 1-dimensional community model with an interface to include or exclude specific processes. (Additional features can be directly suggested on the AWESOME OCIM github repository: github.com/ hengdiliang/AWESOME-OCIM-v1.1).

- Increase openness - Developing open-source models that are available online and published along with the modeling publications to improve testability and reproducibility, through the use of tools like GitHub, BitBucket, or GitLab (e.g., the DOE E3SM model github. com/E3SM-Project).

\section{Acknowledgements}

Funding for this workshop was provided by the National Science Foundation (NSF) grant OCE-1807179 and the U.S. Department of Energy, Office of Biological and Environmental Research. We thank Ashton Dyer and Helen Meskhidze for their technical support to create the web-based interactive $\% \mathrm{DFe}$ vs. $\mathrm{Fe}_{\mathrm{T}}$ plots. The authors are also grateful to Mark Kozak and the rest of the Telluride Science Research Center (TSRC) staff for their help with logistics. We also thank anonymous reviewer for their constructive comments, which helped us to improve the manuscript.

\section{References}

Aguilar-Islas, A.M., Wu, J., Rember, R., Johansen, A.M., Shank, L.M., 2010. Dissolution of aerosol-derived iron in seawater: leach solution chemistry, aerosol type, and colloidal iron fraction. Mar. Chem. 120, 25-33. https://doi.org/10.1016/j.marchem.2009.01. 011.

Al-Abadleh, H.A., 2015. A review on the bulk and surface chemistry of iron in atmospherically-relevant systems containing humic like substances. RSC Adv. 5, 45785-45811. https://doi.org/10.1039/C5RA03132J.

Albani, S., Mahowald, N.M., Murphy, L.N., Raiswell, R., Moore, J.K., Anderson, R.F., McGee, D., Bradtmiller, L.I., Delmonte, B., Hesse, P.P., Mayewski, P.A., 2016. Paleodust variability since the last glacial maximum and implications for iron inputs to the ocean. Geophys. Res. Lett. 43, 3944-3954. https://doi.org/10.1002/ 2016 GL067911. 
Aller, J.Y., Kuznetsova, M.R., Jahns, C.J., Kemp, P.F., 2005. The sea surface microlayer as a source of viral and bacterial enrichment in marine aerosols. J. Aerosol Sci. 36, 801-812. https://doi.org/10.1016/j.jaerosci.2004.10.012.

Arimoto, R., Balsam, W., Schloesslin, C., 2002. Visible spectroscopy of aerosol particles collected on filters: iron-oxide minerals. Atmos. Environ. 36, 89-96. https://doi.org/ 10.1016/S1352-2310(01)00465-4.

Aumont, O., Ethé, C., Tagliabue, A., Bopp, L., Gehlen, M., 2015. PISCES-v2: an ocean biogeochemical model for carbon and ecosystem studies. Geosci. Model Dev. 8, 2465-2513. https://doi.org/10.5194/gmd-8-2465-2015.

Avendaño, L., Gledhill, M., Achterberg, E.P., Rérolle, V.M.C., Schlosser, C., 2016. Influence of ocean acidification on the organic complexation of iron and copper in northwest European shelf seas; a combined observational and model study. Front. Mar. Sci. 3, 58. https://doi.org/10.3389/fmars.2016.00058.

Baker, A.R., Croot, P.L., 2010. Atmospheric and marine controls on aerosol iron solubility in seawater. Mar. Chem. 120, 4-13. https://doi.org/10.1016/j.marchem.2008.09. 003.

Baker, A.R., Jickells, T.D., Witt, M., Linge, K.L., 2006. Trends in the solubility of iron, aluminium, manganese and phosphorus in aerosol collected over the Atlantic Ocean. Mar. Chem. 98, 43-58. https://doi.org/10.1016/j.marchem.2005.06.004.

Baker, A.R., Landing, W.M., Bucciarelli, E., Cheize, M., Fietz, S., Hayes, C.T., Kadko, D., Morton, P.L., Rogan, N., Sarthou, G., Shelley, R.U., Shi, Z., Shiller, A., van Hulten, M.M.P., 2016. Trace element and isotope deposition across the air-sea interface: progress and research needs. Philos. Trans. R. Soc. A. 374, 20160190. https://doi. org/10.1098/rsta.2016.0190.

Basu, S., Shaked, Y., 2018. Mineral iron utilization by natural and cultured Trichodesmium and associated bacteria. Limnol. Oceanogr. 63, 2307-2320. https://doi.org/10.1002/ lno.10939.

Berger, C.J.M., Lippiatt, S.M., Lawrence, M.G., Bruland, K.W., 2008. Application of a chemical leach technique for estimating labile particulate aluminum, iron, and manganese in the Columbia River plume and coastal waters off Oregon and Washington. J. Geophys. Res. 113. https://doi.org/10.1029/2007JC004703.

Bhattachan, A., Reche, I., D'Odorico, P., 2016. Soluble ferrous iron (Fe (II)) enrichment in airborne dust. J. Geophys. Res. Atmos. 121. https://doi.org/10.1002/ 2016JD025025.

Biller, D.V., Bruland, K.W., 2012. Analysis of Mn, Fe, Co, Ni, Cu, Zn, Cd, and Pb in seawater using the Nobias-chelate PA1 resin and magnetic sector inductively coupled plasma mass spectrometry (ICP-MS). Mar. Chem. 130-131, 12-20. https://doi.org/ 10.1016/j.marchem.2011.12.001.

Bonnet, S., Guieu, C., 2004. Dissolution of atmospheric iron in seawater. Geophys. Res. Lett. 31. https://doi.org/10.1029/2003GL018423.

Bowie, A.R., Achterberg, E.P., Mantoura, R.F.C., Worsfold, P.J., 1998. Determination of sub-nanomolar levels of iron in seawater using flow injection with chemiluminescence detection. Anal. Chim. Acta 361, 189-200. https://doi.org/10.1016/S00032670(98)00015-4.

Bowie, A.R., Maldonado, M.T., Frew, R.D., Croot, P.L., Achterberg, E.P., Mantoura, R.F.C., Worsfold, P.J., Law, C.S., Boyd, P.W., 2001. The fate of added iron during a mesoscale fertilisation experiment in the Southern Ocean. Deep-Sea Res. II 48, 2703-2743, https://doi.org/10.1016/S0967-0645(01)00015-7.

Boyd, P.W., Ellwood, M.J., 2010. The biogeochemical cycle of iron in the ocean. Nat. Geosci. 3, 675-682. https://doi.org/10.1038/ngeo964.

Boyd, P.W., Jickells, T., Law, C.S., Blain, S., Boyle, E.A., Buesseler, K.O., Coale, K.H., Cullen, J.J., de Baar, H.J.W., Follows, M., Harvey, M., Lancelot, C., Levasseur, M., Owens, N.P.J., Pollard, R., Rivkin, R.B., Sarmiento, J., Schoemann, V., Smetacek, V., Takeda, S., Tsuda, A., Turner, S., Watson, A.J., 2007. Mesoscale iron enrichment experiments 1993-2005: synthesis and future directions. Science 315, 612-617. https://doi.org/10.1126/science.1131669.

Bressac, M., Guieu, C., 2013. Post-depositional processes: what really happens to new atmospheric iron in the ocean's surface? Glob. Biogeochem. Cycles 27, 859-870. https://doi.org/10.1002/gbc.20076.

Bressac, M., Guieu, C., Doxaran, D., Bourrin, F., Obolensky, G., Grisoni, J.-M., 2012. A mesocosm experiment coupled with optical measurements to assess the fate and sinking of atmospheric particles in clear oligotrophic waters. Geo-Mar. Lett. 32, 153-164. https://doi.org/10.1007/s00367-011-0269-4.

Bressac, M., Guieu, C., Doxaran, D., Bourrin, F., Desboeufs, K., Leblond, N., Ridame, C., 2014. Quantification of the lithogenic carbon pump following a simulated dust-deposition event in large mesocosms. Biogeosciences 11, 1007-1020. https://doi.org/ 10.5194/bg-11-1007-2014.

Brévière, E.H.G., Bakker, D.C.E., Bange, H.W., Bates, T.S., Bell, T.G., Boyd, P.W., Duce, R.A., Garçon, V., Johnson, M.T., Law, C.S., Marandino, C.A., Olsen, A., Quack, B., Quinn, P.K., Sabine, C.L., Saltzman, E.S., 2015. Surface ocean-lower atmosphere study: scientific synthesis and contribution to earth system science. Anthropocene 12, 54-68. https://doi.org/10.1016/j.ancene.2015.11.001.

Buck, C.S., Landing, W.M., Resing, J.A., Lebon, G.T., 2006. Aerosol iron and aluminum solubility in the northwest Pacific Ocean: results from the 2002 IOC cruise. Geochem. Geophys. Geosyst. 7, Q04M07. https://doi.org/10.1029/2005GC000977.

Buck, C.S., Landing, W.M., Resing, J.A., Measures, C.I., 2010. The solubility and deposition of aerosol Fe and other trace elements in the North Atlantic Ocean: observations from the A16N CLIVAR/CO2 repeat hydrography section. Mar. Chem. 120, 57-70. https://doi.org/10.1016/j.marchem.2008.08.003.

Buck, C.S., Landing, W.M., Resing, J., 2013. Pacific ocean aerosols: deposition and solubility of iron, aluminum, and other trace elements. Mar. Chem. 157, 117-130. https://doi.org/10.1016/j.marchem.2013.09.005.

Brévière, E, the SOLAS Scientific Steering Committee (Eds.), 2016. SOLAS 2015- 2025: Science Plan and Organisation. SOLAS International Project Office. GEOMAR Helmholtz Centre for Ocean Research Kiel, Kiel.

Buck, K.N., Gerringa, L.J.A., Rijkenberg, M.J.A., 2016. An Intercomparison of dissolved iron speciation at the Bermuda Atlantic Time-series Study (BATS) site: results from geotraces crossover station A. Front. Mar. Sci. 3. https://doi.org/10.3389/fmars. 2016.00262.

Bundy, R.M., Abdulla, H.A.N., Hatcher, P.G., Biller, D.V., Buck, K.N., Barbeau, K.A., 2015. Iron-binding ligands and humic substances in the San Francisco Bay estuary and estuarine-influenced shelf regions of coastal California. Mar. Chem. 173, 183-194. https://doi.org/10.1016/j.marchem.2014.11.005.

Cheize, M., Sarthou, G., Croot, P.L., Bucciarelli, E., Baudoux, A.-C., Baker, A.R., 2012. Iron organic speciation determination in rainwater using cathodic stripping voltammetry. Anal. Chim. Acta 736, 45-54. https://doi.org/10.1016/j.aca.2012.05.011.

Chen, M., Wang, W.-X., 2001. Bioavailability of natural colloid-bound iron to marine plankton: influences of colloidal size and aging. Limnol. Oceanogr. 46, 1956-1967.

Chen, Y., Street, J., Paytan, A., 2006. Comparison between pure-water- and seawatersoluble nutrient concentrations of aerosols from the Gulf of Aqaba. Mar. Chem. 101, 141-152. https://doi.org/10.1016/j.marchem.2006.02.002.

Chien, C.-T., Mackey, K.R.M., Dutkiewicz, S., Mahowald, N.M., Prospero, J.M., Paytan, A., 2016. Effects of African dust deposition on phytoplankton in the western tropical Atlantic Ocean off Barbados: dust deposition and phytoplankton growth. Glob. Biogeochem. Cycles 30, 716-734. https://doi.org/10.1002/2015GB005334.

Chuang, P.Y., Duvall, R.M., Shafer, M.M., Schauer, J.J., 2005. The origin of water soluble particulate iron in the Asian atmospheric outflow. Geophys. Res. Lett. 32https://doi. org/10.1029/2004GL021946. n/a-n/a.

Chung, C.E., Ramanathan, V., Kim, D., Podgorny, I.A., 2005. Global anthropogenic aerosol direct forcing derived from satellite and ground-based observations. J. Geophys. Res. 110. https://doi.org/10.1029/2005JD006356.

Claquin, T., Schulz, M., Balkanski, Y.J., 1999. Modeling the mineralogy of atmospheric dust sources. J. Geophys. Res. Atmos. 104, 22243-22256. https://doi.org/10.1029/ 1999JD900416.

Conway, T.M., John, S.G., 2014. Quantification of dissolved iron sources to the North Atlantic Ocean. Nature 511, 212-215. https://doi.org/10.1038/nature13482.

Conway, T.M., Hamilton, D.S., Shelley, R.U., Aguilar-Islas, A.M., Landing, W.M., Mahowald, N.M., John, S.G., 2019. Tracing and constraining anthropogenic aerosol iron fluxes to the North Atlantic Ocean using iron isotopes. Nat. Commun. 10. https://doi.org/10.1038/s41467-019-10457-w.

Croot, P.L., Heller, M.I., 2012. The importance of kinetics and redox in the biogeochemical cycling of iron in the Surface Ocean. Front. Microbiol. 3. https://doi.org/ 10.3389/fmicb.2012.00219.

Croot, P.L., Bluhm, K., Schlosser, C., Streu, P., Breitbarth, E., Frew, R., Van Ardelan, M., 2008. Regeneration of Fe(II) during EIFeX and SOFeX. Geophys. Res. Lett. 35 https://doi.org/10.1029/2008GL035063.

Cunliffe, M., Engel, A., Frka, S., Gašparović, B., Guitart, C., Murrell, J.C., Salter, M., Stolle, C., Upstill-Goddard, R., Wurl, O., 2013. Sea surface microlayers: a unified physicochemical and biological perspective of the air-ocean interface. Prog. Oceanogr. 109, 104-116. https://doi.org/10.1016/j.pocean.2012.08.004.

Cutter, G., 2018. Sampling and Sample-handling Protocols for Geotraces Cruises. pp. 178

Dammshäuser, A., Croot, P.L., 2012. Low colloidal associations of aluminium and titanium in surface waters of the tropical Atlantic. Geochim. Cosmochim. Acta 96, 304-318. https://doi.org/10.1016/j.gca.2012.07.032.

Danielson, P.B., 2002. The cytochrome P450 superfamily: biochemistry, evolution and drug metabolism in humans. Curr. Drug Metab. 3 (6), 561-597.

Dedik, A.N., Hoffmann, P., Ensling, J., 1992. Chemical characterization of iron in atmospheric aerosols. Atmos. Environ. Part A 26, 2545-2548. https://doi.org/10. 1016/0960-1686(92)90106-U.

Deguillaume, L., Leriche, M., Desboeufs, K., Mailhot, G., George, C., Chaumerliac, N., 2005. Transition metals in atmospheric liquid phases: sources, reactivity, and sensitive parameters. Chem. Rev. 105, 3388-3431. https://doi.org/10.1021/cr040649c.

Derjaguin, B.V., Churaev, N.V., Muller, V.M., 1987. The Derjaguin-Landau-Verwey-Overbeek (DLVO) theory of stability of lyophobic colloids. In: Derjaguin, B.V., Churaev, N.V., Muller, V.M. (Eds.), Surface Forces. Springer US, Boston, MA, pp. 293-310. https://doi.org/10.1007/978-1-4757-663948.

Duce, R.A., Liss, P.S., 2011. Workshop on Modelling and Observing the Impacts of Dust Transport/Deposition on Marine Productivity.

Duce, R.A., Tindale, N.W., 1991. Atmospheric transport of iron and its deposition in the ocean. Limnol. Oceanogr. 36, 1715-1726.

Duce, R.A., Quinn, J.G., Olney, C.E., Piotrowicz, S.R., Ray, B.J., Wade, T.L., 1972 Enrichment of heavy metals and organic compounds in the surface microlayer of Narragansett Bay, Rhode Island. Science 176, 161-163.

Duce, R.A., Liss, P.S., Merrill, J.T., Atlas, E.L., Buat-Menard, P., Hicks, B.B., Miller, J.M., Prospero, J.M., Arimoto, R., Church, T.M., Ellis, W., Galloway, J.N., Hansen, L., Jickells, T.D., Knap, A.H., Reinhardt, K.H., Schneider, B., Soudine, A., Tokos, J.J., Tsunogai, S., Wollast, R., Zhou, M., 1991. The atmospheric input of trace species to the world ocean. Glob. Biogeochem. Cycles 5, 193-259. https://doi.org/10.1029/ $91 \mathrm{~GB} 01778$.

Dudhaiya, A., Santos, R., 2018. How characterization of particle size distribution pre- and post-reaction provides mechanistic insights into mineral carbonation. Geosciences 8 , 260. https://doi.org/10.3390/geosciences8070260.

Duggen, S., Olgun, N., Croot, P., Hoffmann, L., Dietze, H., Delmelle, P., Teschner, C., 2010. The Role of Airborne Volcanic Ash for the Surface Ocean Biogeochemical Iron Cycle: A Review. pp. 18.

Dunne, J.P., Hales, B., Toggweiler, J.R., 2012. Global calcite cycling constrained by sediment preservation controls. Glob. Biogeochem. Cycles 26. https://doi.org/10. 1029/2010GB003935.

Dunne, J.P., John, J.G., Shevliakova, E., Stouffer, R.J., Krasting, J.P., Malyshev, S.L., Milly, P.C.D., Sentman, L.T., Adcroft, A.J., Cooke, W., et al., 2013. GFDL's ESM2 global coupled climate-carbon earth system models. Part II: carbon system 
formulation and baseline simulation characteristics. J. Clim. 26, 2247-2267.

Durrieu de Madron, X., Ramondenc, S., Berline, L., Houpert, L., Bosse, A., Martini, S., Guidi, L., Conan, P., Curtil, C., Delsaut, N., Kunesch, S., Ghiglione, J.F., Marsaleix, P., Pujo-Pay, M., Séverin, T., Testor, P., Tamburini, C., the ANTARES collaboration, 2017. Deep sediment resuspension and thick nepheloid layer generation by openocean convection: bnl generation by open-ocean convection. J. Geophys. Res. Oceans 122, 2291-2318. https://doi.org/10.1002/2016JC012062.

Ebling, A.M., Landing, W.M., 2017. Trace elements in the sea surface microlayer: rapid responses to changes in aerosol deposition. Elem Sci Anth 5, 42. https://doi.org/10. 1525/elementa.237.

Elrod, V.A., Johnson, K.S., Coale, K.H., 1991. Determination of subnanomolar levels of iron(II) and total dissolved iron in seawater by flow injection and analysis with chemiluminescence detection. Anal. Chem. 63, 893-898. https://doi.org/10.1021/ ac00009a011.

Fan, S.-M., Moxim, W.J., Levy, H., 2006. Aeolian input of bioavailable iron to the ocean. Geophys. Res. Lett. 33. https://doi.org/10.1029/2005GL024852.

Fishwick, M.P., Sedwick, P.N., Lohan, M.C., Worsfold, P.J., Buck, K.N., Church, T.M Ussher, S.J., 2014. The impact of changing surface ocean conditions on the dissolution of aerosol iron: aerosol iron dissolution in seawater. Glob. Biogeochem. Cycles 28, 1235-1250. https://doi.org/10.1002/2014GB004921.

Fitzsimmons, J.N., Carrasco, G.G., Wu, J., Roshan, S., Hatta, M., Measures, C.I., Conway, T.M., John, S.G., Boyle, E.A., 2015a. Partitioning of dissolved iron and iron isotopes into soluble and colloidal phases along the GA03 GEOTRACES North Atlantic transect. Deep-Sea Res. II 116, 130-151. https://doi.org/10.1016/j.dsr2.2014.11. 014.

Fitzsimmons, J.N., Hayes, C.T., Al-Subiai, S.N., Zhang, R., Morton, P.L., Weisend, R.E., Ascani, F., Boyle, E.A., 2015b. Daily to decadal variability of size-fractionated iron and iron-binding ligands at the Hawaii Ocean time-series station ALOHA. Geochim. Cosmochim. Acta 171, 303-324. https://doi.org/10.1016/j.gca.2015.08.012.

Fu, P., Kawamura, K., Miura, K., 2011. Molecular characterization of marine organic aerosols collected during a round-the-world cruise. J. Geophys. Res. 116. https://doi. org/10.1029/2011JD015604.

Fung, I.Y., Meyn, S.K., Tegen, I., Doney, S.C., John, J.G., Bishop, J.K.B., 2000. Iron supply and demand in the upper ocean. Glob. Biogeochem. Cycles 14, 281-295. https://doi. org/10.1029/1999GB900059.

Gantt, B., Meskhidze, N., 2013. The physical and chemical characteristics of marine primary organic aerosol: a review. Atmos. Chem. Phys. 13, 3979-3996. https://doi. org/10.5194/acp-13-3979-2013.

Gassó, S., Stein, A.F., 2007. Does dust from Patagonia reach the sub-Antarctic Atlantic Ocean? Geophys. Res. Lett. 34. https://doi.org/10.1029/2006GL027693.

Gilbert, B., Lu, G., Kim, C.S., 2007. Stable cluster formation in aqueous suspensions of iron oxyhydroxide nanoparticles. J. Colloid Interface Sci. 313, 152-159. https://doi. org/10.1016/j.jcis.2007.04.038.

Gillette, D., 1978. A wind tunnel simulation of the erosion of soil: effect of soil texture, sandblasting, wind speed, and soil consolidation on dust production. Atmos. Environ. 12, 1735-1743. https://doi.org/10.1016/0004-6981(78)90322-0. 1967.

Gledhill, M., Buck, K.N., 2012. The organic complexation of iron in the marine environment: a review. Front. Microbiol. 3. https://doi.org/10.3389/fmicb.2012. 00069.

Gledhill, M., Gerringa, L.J.A., 2017. The effect of metal concentration on the parameters derived from complexometric titrations of trace elements in seawater-a model study. Front. Mar. Sci. 4. https://doi.org/10.3389/fmars.2017.00254.

Gledhill, M., van den Berg, C.M.G., 1994. Determination of complexation of iron(III) with natural organic complexing ligands in seawater using cathodic stripping voltammetry. Mar. Chem. 47, 41-54. https://doi.org/10.1016/0304-4203(94)90012-4.

Gledhill, M., van den Berg, C.M.G., 1995. Measurement of the redox speciation of iron in seawater by catalytic cathodic stripping voltammetry. Mar. Chem. 50, 51-61. https://doi.org/10.1016/0304-4203(95)00026-N.

Goldstein, A.H., Galbally, I.E., 2007. Known and unexplored organic constituents in the earth's atmosphere. Environ. Sci. Technol. 41, 1514-1521. https://doi.org/10.1021/ es072476p.

Gordon, R.M., Johnson, K.S., Coale, K.H., 1998. The behaviour of iron and other trace elements during the IronEx-I and PlumEx experiments in the Equatorial Pacific. DeepSea Res. II 45, 995-1041. https://doi.org/10.1016/S0967-0645(98)00012-5.

Graham, B., 2002. Water-soluble organic compounds in biomass burning aerosols over Amazonia 1. Characterization by NMR and GC-MS. J. Geophys. Res. 107. https://doi. org/10.1029/2001JD000336.

Guieu, C., Bonnet, S., Wagener, T., Loÿe-Pilot, M.-D., 2005. Biomass burning as a source of dissolved iron to the open ocean? Geophys. Res. Lett. 32https://doi.org/10.1029/ 2005GL022962. N/a-N/a.

Guieu, C., Dulac, F., Ridame, C., Pondaven, P., 2014. Introduction to project DUNE, a DUst experiment in a low nutrient, low chlorophyll ecosystem. Biogeosciences 11, 425-442. https://doi.org/10.5194/bg-11-425-2014.

Hassler, C.S., Alasonati, E., Mancuso Nichols, C.A., Slaveykova, V.I., 2011a. Exopolysaccharides produced by bacteria isolated from the pelagic Southern Ocean role in Fe binding, chemical reactivity, and bioavailability. Mar. Chem. 123, 88-98. https://doi.org/10.1016/j.marchem.2010.10.003.

Hassler, C.S., Schoemann, V., Nichols, C.M., Butler, E.C.V., Boyd, P.W., 2011b. Saccharides enhance iron bioavailability to Southern Ocean phytoplankton. Proc. Natl. Acad. Sci. 108, 1076-1081. https://doi.org/10.1073/pnas.1010963108.

Hawkins, L.N., Russell, L.M., 2010. Polysaccharides, proteins, and phytoplankton fragments: four chemically distinct types of marine primary organic aerosol classified by single particle spectromicroscopy. Adv. Meteorol. 2010, 1-14. https://doi.org/10. $1155 / 2010 / 612132$

Hayes, C.T., Anderson, R.F., Cheng, H., Conway, T.M., Edwards, R.L., Fleisher, M.Q., Ho, P., Huang, K.F., John, S.G., Landing, W.M., Little, S.H., Lu, Y., Morton, P.L., Moran,
S.B., Robinson, L.F., Shelley, R.U., Shiller, A.M., Zheng, X.Y., 2018. Replacement times of a spectrum of elements in the North Atlantic based on thorium supply. Glob. Biogeochem. Cycles 32, 1294-1311. https://doi.org/10.1029/2017GB005839.

Henrichs, S.M., Williams, P.M., 1985. Dissolved and particulate amino acids and carbohydrates in the sea surface microlayer. Mar. Chem. 17, 141-163. https://doi.org/10 1016/0304-4203(85)90070-2.

Herrmann, H., Ervens, B., Nowacki, P., Zellner, R., 2000. CAPRAM2.3: a chemical aqueous phase radical mechanism for tropospheric chemistry. J. Atmos. Chem. 36, 231-284.

Herut, B., Rahav, E., Tsagaraki, T.M., Giannakourou, A., Tsiola, A., Psarra, S., Lagaria, A., Papageorgiou, N., Mihalopoulos, N., Theodosi, C.N., Violaki, K., Stathopoulou, E., Scoullos, M., Krom, M.D., Stockdale, A., Shi, Z., Berman-Frank, I., Meador, T.B.,

Tanaka, T., Paraskevi, P., 2016. The potential impact of Saharan dust and polluted aerosols on microbial populations in the East Mediterranean Sea, an overview of a Mesocosm experimental approach. Front. Mar. Sci. 3. https://doi.org/10.3389/ fmars.2016.00226.

Hoffmann, P., Dedik, A.N., Ensling, J., Weinbruch, S., Weber, S., Sinner, T., Gütlich, P., Ortner, H.M., 1996. Speciation of iron in atmospheric aerosol samples. J. Aerosol Sci. 27, 325-337. https://doi.org/10.1016/0021-8502(95)00563-3.

Hudson, R.J.M., Morel, F.M.M., 1990. Iron transport in marine phytoplankton: kinetics of cellular and medium coordination reactions. Limnol. Oceanogr. 35, 1002-1020.

Hunter, K.A., Boyd, P.W., 2007. Iron-binding ligands and their role in the ocean biogeochemistry of iron. Environ. Chem. 4, 221. https://doi.org/10.1071/EN07012.

Ingall, E., Feng, Y., Longo, A., Lai, B., Shelley, R., Landing, W., Morton, P., Nenes, A., Mihalopoulos, N., Violaki, K., Gao, Y., Sahai, S., Castorina, E., 2018. Enhanced iron solubility at low pH in global aerosols. Atmosphere 9, 201. https://doi.org/10.3390/ atmos9050201.

IPCC, 2013. Climate Change 2013: the Physical Science Basis: Summary for Policymakers. (Cambridge, UK).

Ito, A., 2011. Mega fire emissions in Siberia: potential supply of bioavailable iron from forests to the ocean. Biogeosciences 8, 1679-1697. https://doi.org/10.5194/bg-81679-2011.

Ito, A., 2013. Global modeling study of potentially bioavailable iron input from shipboard aerosol sources to the ocean. Glob. Biogeochem. Cycles 27, 1-10. https://doi.org/10. 1029/2012GB004378.

Ito, A., Feng, Y., 2010. Role of dust alkalinity in acid mobilization of iron. Atmos. Chem. Phys. 14.

Ito, A., Shi, Z., 2016. Delivery of anthropogenic bioavailable iron from mineral dust and combustion aerosols to the ocean. Atmos. Chem. Phys. 16, 85-99. https://doi.org/10. 5194/acp-16-85-2016.

Ito, A., Xu, L., 2014. Response of acid mobilization of iron-containing mineral dust to improvement of air quality projected in the future. Atmos. Chem. Phys. 14, 3441-3459. https://doi.org/10.5194/acp-14-3441-2014.

Ito, A., Myriokefalitakis, S., Kanakidou, M., Mahowald, N.M., Scanza, R.A., Hamilton, D.S., Baker, A.R., Jickells, T., Sarin, M., Bikkina, S., Gao, Y., Shelley, R.U., Buck, C.S., Landing, W.M., Bowie, A.R., Perron, M.M.G., Guieu, C., Meskhidze, N., Johnson, M.S., Feng, Y., Kok, J.F., Nenes, A., Duce, R.A., 2019a. Pyrogenic iron: the missing link to high iron solubility in aerosols. Sci. Adv. 5, eaau7671. https://doi.org/10. 1126/sciadv.aau7671.

Ito, A., Ye, Y., Yamamoto, A., Watanabe, M., Aita, M.N., 2019. Responses of Ocean Biogeochemistry to Atmospheric Supply of Lithogenic and Pyrogenic Iron-Containing Aerosols. Geol. Mag.https://doi.org/10.1017/S0016756819001080. In press.

Jickells, T.D., 1999. The inputs of dust derived elements to the Sargasso Sea; a synthesis. Mar. Chem. 68, 5-14. https://doi.org/10.1016/S0304-4203(99)00061-4.

Jickells, T.D., An, Z.S., Andersen, K.K., Baker, A.R., Bergametti, G., Brooks, N., Cao, J.J., Boyd, P.W., Duce, R.A., Hunter, K.A., et al., 2005. Global iron connections between desert dust, ocean biogeochemistry, and climate. Science 308, 67-71.

Johansen, A.M., Key, J.M., 2006. Photoreductive dissolution of ferrihydrite by methanesulfinic acid: evidence of a direct link between dimethylsulfide and iron-bioavailability. Geophys. Res. Lett. 33. https://doi.org/10.1029/2006GL026010.

Johnson, K., 2001. Iron supply and demand in the upper ocean: is extraterrestrial dust a significant source of bioavailable iron? Glob. Biogeochem. Cycles 15, 61-63. https:// doi.org/10.1029/2000GB001295.

Johnson, M.S., Meskhidze, N., 2013. Atmospheric dissolved iron deposition to the global oceans: effects of oxalate-promoted Fe dissolution, photochemical redox cycling, and dust mineralogy. Geosci. Model Dev. 6, 1137-1155. https://doi.org/10.5194/gmd-61137-2013.

Johnson, K.S., Gordon, R.M., Coale, K.H., 1997. What controls dissolved iron concentrations in the world ocean? Mar. Chem. 57, 137-161. https://doi.org/10.1016/ S0304-4203(97)00043-1.

Johnson, K.S., Boyle, E., Bruland, K., Coale, K., Measures, C., Moffett, J., Aguilar-Islas, A., Barbeau, K., Bergquist, B., Bowie, A., Buck, K., Cai, Y., Chase, Z., Cullen, J., Doi, T., Elrod, V., Fitzwater, S., Gordon, M., King, A., Laan, P., Laglera-Baquer, L., Landing, W., Lohan, M., Mendez, J., Milne, A., Obata, H., Ossiander, L., Plant, J., Sarthou, G., Sedwick, P., Smith, G.J., Sohst, B., Tanner, S., Van den Berg, S., Wu, J., 2007. Developing standards for dissolved iron in seawater. EOS Trans. Am. Geophys. Union 88, 131. https://doi.org/10.1029/2007EO110003.

Johnson, M.S., Meskhidze, N., Kiliyanpilakkil, V.P., Gassó, S., 2011. Understanding the transport of Patagonian dust and its influence on marine biological activity in the South Atlantic Ocean. Atmos. Chem. Phys. 11, 2487-2502. https://doi.org/10.5194/ acp-11-2487-2011.

Journet, E., Desboeufs, K.V., Caquineau, S., Colin, J.-L., 2008. Mineralogy as a critical factor of dust iron solubility. Geophys. Res. Lett. 35, L07805. https://doi.org/10. 1029/2007GL031589.

Journet, E., Balkanski, Y., Harrison, S.P., 2014. A new data set of soil mineralogy for dustcycle modeling. Atmos. Chem. Phys. 14, 3801-3816. https://doi.org/10.5194/acp- 
14-3801-2014.

Kadko, D., Landing, W.M., Shelley, R.U., 2015. A novel tracer technique to quantify the atmospheric flux of trace elements to remote ocean regions. J. Geophys. Res. Oceans 120, 848-858. https://doi.org/10.1002/2014JC010314.

Kanakidou, M., Myriokefalitakis, S., Tsigaridis, K., 2018. Aerosols in atmospheric chemistry and biogeochemical cycles of nutrients. Environ. Res. Lett. 13. https://doi.org/ 10.1088/1748-326/aabcdb.

Kanna, N., Nishioka, J., 2016. Bio-availability of iron derived from subarctic first-year sea ice. Mar. Chem. 186, 189-197. https://doi.org/10.1016/j.marchem.2016.09.009.

Kawamura, K., 1993. Identification of C2-C10 .omega.-oxocarboxylic acids, pyruvic acid, and C2-C3 .alpha.-dicarbonyls in wet precipitation and aerosol samples by capillary GC and GC/MS. Anal. Chem. 65, 3505-3511. https://doi.org/10.1021/ac00071a030.

Kieber, R.J., Williams, K.H., Willey, J.D., Skrabal, S.A., Avery Jr., G.B., 2001. Iron speciation in coastal rainwater: concentration and deposition to seawater. Mar. Chem. 73, 83-95.

Kieber, R.J., Skrabal, S.A., Smith, B.J., Willey, J.D., 2005. Organic complexation of Fe(II) and its impact on the redox cycling of iron in rain. Environ. Sci. Technol. 39, 1576-1583. https://doi.org/10.1021/es040439h.

Kok, J.F., 2011. A scaling theory for the size distribution of emitted dust aerosols suggests climate models underestimate the size of the global dust cycle. Proc. Natl. Acad. Sci. 108, 1016-1021.

Krishnamurthy, A., Moore, J.K., Mahowald, N., Luo, C., Zender, C.S., 2010. Impacts of atmospheric nutrient inputs on marine biogeochemistry. J. Geophys. Res. 115. https://doi.org/10.1029/2009JG001115.

Kuznetsova, M., Lee, C., 2002. Dissolved Free and Combined Amino Acids in Nearshore Seawater, Sea Surface Microlayers and Foams: Influence of Extracellular Hydrolysis. vol. 64. pp. 17.

Laglera, L.M., van den Berg, C.M.G., 2009. Evidence for geochemical control of iron by humic substances in seawater. Limnol. Oceanogr. 54, 610-619. https://doi.org/10. 4319/1o.2009.54.2.0610.

Laglera, L.M., Battaglia, G., van den Berg, C.M.G., 2011. Effect of humic substances on the iron speciation in natural waters by CLE/CSV. Mar. Chem. 127, 134-143. https://doi. org/10.1016/j.marchem.2011.09.003.

Landing, W.M., Bruland, K.W., 1987. The contrasting biogeochemistry of iron and manganese in the Pacific Ocean. Geochim. Cosmochim. Acta 51, 29-43.

Langmann, B., ZakĹĄek, K., Hort, M., Duggen, S., 2010. Volcanic ash as fertiliser for the surface ocean. Atmos. Chem. Phys. 10, 3891-3899.

Lim, B., Jickells, T.D., 1990. Dissolved, particulate and acid-leachable trace metal concentrations in North Atlantic precipitation collected on the global change expedition. Glob. Biogeochem. Cycles 4, 445-458. https://doi.org/10.1029/GB004i004p00445.

Lindenthal, A., Langmann, B., Pätsch, J., Lorkowski, I., Hort, M., 2013. The ocean response to volcanic iron fertilisation after the eruption of Kasatochi volcano: a regional-scale biogeochemical ocean model study. Biogeosciences 10, 3715-3729. https://doi.org/10.5194/bg-10-3715-2013.

Lis, H., Kranzler, C., Keren, N., Shaked, Y., 2015. A comparative study of Iron uptake rates and mechanisms amongst marine and fresh water cyanobacteria: prevalence of reductive iron uptake. Life 5, 841-860. https://doi.org/10.3390/life5010841.

Liss, P.S., Duce, R.A., 2005. The Sea Surface and Global Change. Cambridge University Press, UK. https://doi.org/10.1017/CBO9780511525025.

Liu, X., Millero, F.J., 2002. The solubility of iron in seawater. Mar. Chem. 77, 43-54. https://doi.org/10.1016/S0304-4203(01)00074-3.

Liu, H., Jacob, D.J., Bey, I., Yantosca, R.M., 2001. Constraints from 210Pb and 7Be on wet deposition and transport in a global three-dimensional chemical tracer model driven by assimilated meteorological fields. J. Geophys. Res. 106, 12109-12128. https:// doi.org/10.1029/2000JD900839.

Lohan, M.C., Aguilar-Islas, A.M., Franks, R.P., Bruland, K.W., 2005. Determination of iron and copper in seawater at $\mathrm{pH} 1.7$ with a new commercially available chelating resin, NTA superflow. Anal. Chim. Acta 530, 121-129. https://doi.org/10.1016/j.aca.2004. 09.005.

Louis, J., Pedrotti, M.L., Gazeau, F., Guieu, C., 2017. Experimental evidence of formation of transparent exopolymer particles (TEP) and POC export provoked by dust addition under current and high pCO2 conditions. PLoS One 12, e0171980. https://doi.org/ 10.1371/journal.pone.0171980.

Luo, C., Mahowald, N., Bond, T., Chuang, P.Y., Artaxo, P., Siefert, R., Chen, Y., Schauer, J., 2008. Combustion iron distribution and deposition. Glob. Biogeochem. Cycles 22https://doi.org/10.1029/2007GB002964. n/a-n/a

Mackey, K.R.M., Chien, C.-T., Post, A.F., Saito, M.A., Paytan, A., 2015. Rapid and gradual modes of aerosol trace metal dissolution in seawater. Front. Microbiol. 5. https://doi. org /10.3389/fmicb.2014.00794.

Mackie, D.S., Peat, J.M., McTainsh, G.H., Boyd, P.W., Hunter, K.A., 2006. Soil abrasion and eolian dust production: implications for iron partitioning and solubility. Geochem. Geophys. Geosyst. 7, Q12Q03. https://doi.org/10.1029/2006GC001404.

Mahowald, N.M., Engelstaedter, S., Luo, C., Sealy, A., Artaxo, P., Benitez-Nelson, C., Bonnet, S., Chen, Y., Chuang, P.Y., Cohen, D.D., Dulac, F., Herut, B., Johansen, A.M., Kubilay, N., Losno, R., Maenhaut, W., Paytan, A., Prospero, J.M., Shank, L.M., Siefert, R.L., 2009. Atmospheric iron deposition: global distribution, variability, and human perturbations. Annu. Rev. Mar. Sci. 1, 245-278. https://doi.org/10.1146/annurev. marine.010908.163727

Mahowald, N.M., Hamilton, D.S., Mackey, K.R.M., Moore, J.K., Baker, A.R., Scanza, R.A., Zhang, Y., 2018. Aerosol trace metal leaching and impacts on marine microorganisms. Nat. Commun. 9. https://doi.org/10.1038/s41467-018-04970-7.

Maldonado, M.T., Price, N.M., 2001. Reduction and transport of organically bound iron by Thalassiosira oceanica (Bacillariophyceae). J. Phycol. 37, 298-310. https://doi. org/10.1046/j.1529-8817.2001.037002298.x.

Mao, J., Fan, S., Jacob, D.J., Travis, K.R., 2013. Radical loss in the atmosphere from Cu-Fe redox coupling in aerosols. Atmos. Chem. Phys. 13, 509-519. https://doi.org/10. 5194/acp-13-509-2013

Mao, J., Fan, S., Horowitz, L.W., 2017. Soluble Fe in aerosols sustained by gaseous HO uptake. Environ. Sci. Technol. Lett. 4, 98-104. https://doi.org/10.1021/acs.estlett. $7 \mathrm{~b} 00017$.

Martin, J.H., Gordon, R.M., 1988. Northeast Pacific iron distributions in relation to phytoplankton productivity. Deep Sea Res. Part A. Oceanogr. Res. Pap. 35, 177-196.

Matsui, H., Mahowald, N.M., Moteki, N., Hamilton, D.S., Ohata, S., Yoshida, A., Koike, M., Scanza, R.A., Flanner, M.G., 2018. Anthropogenic combustion iron as a complex climate forcer. Nat. Commun. 9. https://doi.org/10.1038/s41467-018-03997-0.

Mawji, E., Gledhill, M., Milton, J.A., Tarran, G.A., Ussher, S., Thompson, A., Wolff, G.A., Worsfold, P.J., Achterberg, E.P., 2008. Hydroxamate siderophores: occurrence and importance in the Atlantic Ocean. Environ. Sci. Technol. 42, 8675-8680. https://doi. org $/ 10.1021 /$ es801884r.

McQuaid, J.B., Kustka, A.B., Oborník, M., Horák, Aleš, McCrow, J.P., Karas, B.J., Zheng, H., Kindeberg, T., Andersson, A.J., Barbeau, K.A., Allen, A.E., 2018. Carbonate-sensitive phytotransferrin controls high-affinity iron uptake in diatoms. Nature 555, 534-537. https://doi.org/10.1038/nature25982.

Measures, C.I., Vink, S., 2000. On the use of dissolved aluminum in surface waters to estimate dust deposition to the ocean. Glob. Biogeochem. Cycles 14, 317-327. https://doi.org/10.1029/1999GB001188.

Measures, C.I., Yuan, J., Resing, J.A., 1995. Determination of iron in seawater by flow injection analysis using in-line preconcentration and spectrophotometric detection. Mar. Chem. 50, 3-12. https://doi.org/10.1016/0304-4203(95)00022-J.

Meskhidze, N., Chameides, W.L., Nenes, A., Chen, G., 2003. Iron mobilization in mineral dust: can anthropogenic $\mathrm{SO}_{2}$ emissions affect ocean productivity? Geophys. Res. Lett. 30, 2085. https://doi.org/10.1029/2003GL018035.

Meskhidze, N., Chameides, W.L., Nenes, A., 2005. Dust and pollution: a recipe for enhanced ocean fertilization? J. Geophys. Res. 110, D03301. https://doi.org/10.1029/ 2004JD005082.

Meskhidze, N., Johnson, M.S., Hurley, D., Dawson, K., 2016. Influence of measurement uncertainties on fractional solubility of iron in mineral aerosols over the oceans. Aeolian Res. 22, 85-92. https://doi.org/10.1016/j.aeolia.2016.07.002.

Meskhidze, N., Hurley, D., Royalty, T.M., Johnson, M.S., 2017. Potential effect of atmospheric dissolved organic carbon on the iron solubility in seawater. Mar. Chem. 194, 124-132. https://doi.org/10.1016/j.marchem.2017.05.011.

Misumi, K., Lindsay, K., Moore, J.K., Doney, S.C., Tsumune, D., Yoshida, Y., 2013. Humic substances may control dissolved iron distributions in the global ocean: implications from numerical simulations. Glob. Biogeochem. Cycles 27, 450-462. https://doi.org/ 10.1002/gbc. 20039.

Moore, J.K., Doney, S.C., 2007. Iron availability limits the ocean nitrogen inventory stabilizing feedbacks between marine denitrification and nitrogen fixation. Glob. Biogeochem. Cycles 21, GB2001. https://doi.org/10.1029/2006GB002762.

Moore, J.K., Doney, S.C., Lindsay, K., 2004. Upper ocean ecosystem dynamics and iron cycling in a global three-dimensional model. Glob. Biogeochem. Cycles 18, 1-21. https://doi.org/10.1029/2004GB002220.

Moore, C.M., Mills, M.M., Arrigo, K.R., Berman-Frank, I., Bopp, L., Boyd, P.W., Galbraith, E.D., Geider, R.J., Guieu, C., Jaccard, S.L., Jickells, T.D., La Roche, J., Lenton, T.M., Mahowald, N.M., Marañón, E., Marinov, I., Moore, J.K., Nakatsuka, T., Oschlies, A. Saito, M., Thingstad, T.F., Tsuda, A., Ulloa, O., 2013. Processes and patterns of oceanic nutrient limitation. Nat. Geosci. 6, 701-710. https://doi.org/10.1038/ ngeo1765.

Morel, F.M.M., Kustka, A.B., Shaked, Y., 2008. The role of unchelated Fe in the iron nutrition of phytoplankton. Limnol. Oceanogr. 53, 400-404. https://doi.org/10. 4319/10.2008.53.1.0400.

Morrissey, J., Sutak, R., Paz-Yepes, J., Tanaka, A., Moustafa, A., Veluchamy, A., Thomas, Y., Botebol, H., Bouget, F.-Y., McQuaid, J.B., Tirichine, L., Allen, A.E., Lesuisse, E., Bowler, C., 2015. A novel protein, ubiquitous in marine phytoplankton, concentrates iron at the cell surface and facilitates uptake. Curr. Biol. 25, 364-371. https://doi. org/10.1016/j.cub.2014.12.004.

Morton, P.L., Landing, W.M., Hsu, S.-C., Milne, A., Aguilar-Islas, A.M., Baker, A.R., Bowie, A.R., Buck, C.S., Gao, Y., Gichuki, S., Hastings, M.G., Hatta, M., Johansen, A.M., Losno, R., Mead, C., Patey, M.D., Swarr, G., Vandermark, A., Zamora, L.M., 2013 Methods for the sampling and analysis of marine aerosols: results from the 2008 GEOTRACES aerosol intercalibration experiment: GEOTRACES 2008 aerosol Intercalibration. Limnol. Oceanogr. Methods 11, 62-78. https://doi.org/10.4319/ lom.2013.11.62.

Myriokefalitakis, S., Ito, A., Kanakidou, M., Nenes, A., Krol, M.C., Mahowald, N.M., Scanza, R.A., Hamilton, D.S., Johnson, M.S., Meskhidze, N., Kok, J.F., Guieu, C., Baker, A.R., Jickells, T.D., Sarin, M.M., Bikkina, S., Shelley, R., Bowie, A., Perron, M.M.G., Duce, R.A., 2018. Reviews and syntheses: the GESAMP atmospheric iron deposition model intercomparison study. Biogeosciences 15, 6659-6684. https://doi org/10.5194/bg-15-6659-2018.

Nickovic, S., Vukovic, A., Vujadinovic, M., 2013. Atmospheric processing of iron carried by mineral dust. Atmos. Chem. Phys. 13, 9169-9181. https://doi.org/10.5194/acp13-9169-2013.

Oakes, M., Weber, R.J., Lai, B., Russell, A., Ingall, E.D., 2012. Characterization of iron speciation in urban and rural single particles using XANES spectroscopy and micro X ray fluorescence measurements: investigating the relationship between speciation and fractional iron solubility. Atmos. Chem. Phys. 12.

Obata, Hajime, Karatani, Hajime, Nakayama, Eiichiro, 1993. Automated determination of iron in seawater by chelating resin concentration and chemiluminescence detection. Anal. Chem. 65, 1524-1528. https://doi.org/10.1021/ac00059a007.

Ohnemus, D.C., Lam, P.J., 2015. Cycling of lithogenic marine particles in the US GEOTRACES North Atlantic transect. Deep-Sea Res. II 116, 283-302. https://doi.org/ 10.1016/j.dsr2.2014.11.019.

Okin, G.S., Baker, A.R., Tegen, I., Mahowald, N.M., Dentener, F.J., Duce, R.A., Galloway, 
J.N., Hunter, K., Kanakidou, M., Kubilay, N., Prospero, J.M., Sarin, M., Surapipith, V., Uematsu, M., Zhu, T., 2011. Impacts of atmospheric nutrient deposition on marine productivity: roles of nitrogen, phosphorus, and iron. Glob. Biogeochem. Cycles 25, GB2022. https://doi.org/10.1029/2010GB003858.

Parekh, P., Follows, M.J., Boyle, E., 2004. Modeling the global ocean iron cycle. Glob. Biogeochem. Cycles 18, 1-15. https://doi.org/10.1029/2003GB002061.

Parekh, P., Follows, M.J., Boyle, E.A., 2005. Decoupling of iron and phosphate in the global ocean. Glob. Biogeochem. Cycles 19https://doi.org/10.1029/2004GB002280. n/a-n/a.

Paris, R., Desboeufs, K.V., 2013. Effect of atmospheric organic complexation on ironbearing dust solubility. Atmos. Chem. Phys. 13, 4895-4905. https://doi.org/10. 5194/acp-13-4895-2013.

Paris, R., Desboeufs, K.V., Formenti, P., Nava, S., Chou, C., 2010. Chemical characterisation of iron in dust and biomass burning aerosols during AMMA-SOP0/DABEX: implication for iron solubility. Atmos. Chem. Phys. 10, 4273-4282. https://doi.org/ 10.5194/acp-10-4273-2010.

Paris, R., Desboeufs, K.V., Journet, E., 2011. Variability of dust iron solubility in atmospheric waters: investigation of the role of oxalate organic complexation. Atmos. Environ. 45, 6510-6517. https://doi.org/10.1016/j.atmosenv.2011.08.068.

Pasquier, B., Holzer, M., 2017. Inverse-model estimates of the ocean's coupled phosphorus, silicon, and iron cycles. Biogeosciences 14, 4125-4159. https://doi.org/10. 5194/bg-14-4125-2017.

Perlwitz, J.P., Pérez García-Pando, C., Miller, R.L., 2015. Predicting the mineral composition of dust aerosols - part 2: model evaluation and identification of key processes with observations. Atmos. Chem. Phys. 15, 11629-11652. https://doi.org/10. 5194/acp-15-11629-2015.

Piotrowicz, S.R., Ray, B.J., Hoffman, G.L., Duce, R.A., 1972. Trace metal enrichment in the sea-surface microlayer. J. Geophys. Res. 77, 5243-5254. https://doi.org/10. 1029/JC077i027p05243.

Puig, P., Palanques, A., Orange, D.L., Lastras, G., Canals, M., 2008. Dense shelf water cascades and sedimentary furrow formation in the cap de creus canyon, Northwestern Mediterranean Sea. Cont. Shelf Res. 28, 2017-2030. https://doi.org/10.1016/j.csr. 2008.05.002.

Raiswell, R., Canfield, D.E., 2012. The iron biogeochemical cycle past and present. Geochem. Perspect. 1, 1-220. https://doi.org/10.7185/geochempersp.1.1.

Raiswell, R., Hawkings, J.R., Benning, L.G., Albani, S., Mahowald, N., 2017. Comments on 'influence of measurement uncertainties on fractional solubility of iron in mineral aerosols over the oceans' Aeolian research 22, 85-92. Aeolian Res. 25, 123-125. https://doi.org/10.1016/j.aeolia.2017.03.003.

Raven, J.A., 1988. The iron and molybdenum use efficiencies of plant growth with different energy, carbon and nitrogen sources. New Phytol. 109, 279-287.

Raven, J.A., Evans, M.C.W., Korb, R.E., 1999. The role of trace metals in photosynthetic electron transport in O2-evolving organisms. Photosynth. Res. 60, 111-149.

Rich, H.W., Morel, F.M.M., 1990. Availability of well-defined iron colloids to the marine diatom Thalassiosira weissflogii. Limnol. Oceanogr. 35, 652-662. https://doi.org/10. 4319/10.1990.35.3.0652.

Rijkenberg, M.J.A., Middag, R., Laan, P., Gerringa, L.J.A., van Aken, H.M., Schoemann, V., de Jong, J.T.M., de Baar, H.J.W., 2014. The distribution of dissolved Iron in the West Atlantic Ocean. PLoS One 9, 1-14. https://doi.org/10.1371/journal.pone. 0101323.

Röhrl, A., Lammel, G., 2002. Determination of malic acid and other C 4 dicarboxylic acids in atmospheric aerosol samples. Chemosphere 46, 1195-1199.

Rose, A.L., Waite, T.D., 2003. Predicting iron speciation in coastal waters from the kinetics of sunlight-mediated iron redox cycling. Aquat. Sci. Res. Across Bound. 65, 375-383. https://doi.org/10.1007/s00027-003-0676-3.

Rubin, M., Berman-Frank, I., Shaked, Y., 2011. Dust- and mineral-iron utilization by the marine dinitrogen-fixer Trichodesmium. Nat. Geosci. 4, 529-534. https://doi.org/10. 1038/ngeo1181.

Rue, E.L., Bruland, K.W., 1995. Complexation of iron(III) by natural organic ligands in the Central North Pacific as determined by a new competitive ligand equilibration/adsorptive cathodic stripping voltammetric method. Mar. Chem. 50, 117-138.

Santana-Casiano, J.M., González-Dávila, M., Millero, F.J., 2005. Oxidation of nanomolar levels of Fe(II) with oxygen in natural waters. Environ. Sci. Technol. 39, 2073-2079. https://doi.org/10.1021/es049748y.

Scanza, R.A., Mahowald, N., Ghan, S., Zender, C.S., Kok, J.F., Liu, X., Zhang, Y., Albani, S., 2015. Modeling dust as component minerals in the community atmosphere model: development of framework and impact on radiative forcing. Atmos. Chem. Phys. 15, 537-561. https://doi.org/10.5194/acp-15-537-2015.

Schüßler, U., Balzer, W., Deeken, A., 2005. Dissolved Al distribution, particulate Al fluxes and coupling to atmospheric $\mathrm{Al}$ and dust deposition in the Arabian Sea. Deep-Sea Res. II 52, 1862-1878. https://doi.org/10.1016/j.dsr2.2005.06.005.

Schwertmann, U., 1991. Solubility and dissolution of iron oxides. Plant Soil 130, 1-25.

Sedwick, P.N., Sholkovitz, E.R., Church, T.M., 2007. Impact of anthropogenic combustion emissions on the fractional solubility of aerosol iron: evidence from the Sargasso Sea. Geochem. Geophys. Geosyst. 8https://doi.org/10.1029/2007GC001586. Q10Q06.

Sedwick, P.N., Sohst, B.M., Ussher, S.J., Bowie, A.R., 2015. A zonal picture of the water column distribution of dissolved iron(II) during the U.S. GEOTRACES North Atlantic transect cruise (GEOTRACES GA03). Deep-Sea Res. II 116, 166-175. https://doi.org/ 10.1016/j.dsr2.2014.11.004.

Semeniuk, D.M., Taylor, R.L., Bundy, R.M., Johnson, W.K., Cullen, J.T., Robert, M., Barbeau, K.A., Maldonado, M.T., 2016. Iron-copper interactions in iron-limited phytoplankton in the Northeast Subarctic Pacific Ocean: Fe-Cu interactions in HNLC phytoplankton. Limnol. Oceanogr. 61, 279-297. https://doi.org/10.1002/lno.10210.

Semple, K.T., Doick, K.J., Jones, K.C., Burauel, P., Craven, A., Harms, H., 2004. Peer reviewed: defining bioavailability and bioaccessibility of contaminated soil and sediment is complicated. Environ. Sci. Technol. 38, 228A-231A. https://doi.org/10. 1021/es040548w.

Shaked, Y., Lis, H., 2012. Disassembling iron availability to phytoplankton. Front. Microbiol. 3. https://doi.org/10.3389/fmicb.2012.00123.

Shi, Z., Krom, M.D., Bonneville, S., Baker, A.R., Jickells, T.D., Benning, L.G., 2009. Formation of iron nanoparticles and increase in iron reactivity in mineral dust during simulated cloud processing. Environ. Sci. Technol. 43, 6592-6596. https://doi.org/ 10.1021/es901294g.

Shi, Z., Bonneville, S., Krom, M.D., Carslaw, K.S., Jickells, T.D., Baker, A.R., Benning, L.G., 2011a. Iron dissolution kinetics of mineral dust at low pH during simulated atmospheric processing. Atmos. Chem. Phys. 11, 995-1007. https://doi.org/10. 5194/acp-11-995-2011.

Shi, Zongbo, Krom, M.D., Bonneville, S., Baker, A.R., Bristow, C., Drake, N., Mann, G., Carslaw, K., McQuaid, J.B., Jickells, T., Benning, L.G., 2011b. Influence of chemical weathering and aging of iron oxides on the potential iron solubility of Saharan dust during simulated atmospheric processing: weathering and dust Fe solubility. Glob. Biogeochem. Cycles 25https://doi.org/10.1029/2010GB003837. n/a-n/a.

Shi, Z.B., Woodhouse, M.T., Carslaw, K.S., Krom, M.D., Mann, G.W., Baker, A.R., Savov, I., Fones, G.R., Brooks, B., Drake, N., Jickells, T.D., Benning, L.G., 2011c. Minor effect of physical size sorting on iron solubility of transported mineral dust. Atmos. Chem. Phys. 11, 8459-8469. https://doi.org/10.5194/acp-11-8459-2011.

Sholkovitz, E.R., Sedwick, P.N., Church, T.M., 2009. Influence of anthropogenic combustion emissions on the deposition of soluble aerosol iron to the ocean: empirical estimates for island sites in the North Atlantic. Geochim. Cosmochim. Acta 73, 3981-4003. https://doi.org/10.1016/j.gca.2009.04.029.

Sholkovitz, E.R., Sedwick, P.N., Church, T.M., Baker, A.R., Powell, C.F., 2012. Fractional solubility of aerosol iron: synthesis of a global-scale data set. Geochim. Cosmochim. Acta 89, 173-189. https://doi.org/10.1016/j.gca.2012.04.022.

Slikboer, S., Grandy, L., Blair, S.L., Nizkorodov, S.A., Smith, R.W., Al-Abadleh, H.A., 2015. Formation of light absorbing soluble secondary organics and insoluble polymeric particles from the dark reaction of catechol and guaiacol with Fe(III). Environ. Sci. Technol. 49, 7793-7801. https://doi.org/10.1021/acs.est.5b01032.

Solmon, F., Chuang, P.Y., Meskhidze, N., Chen, Y., 2009. Acidic processing of mineral dust iron by anthropogenic compounds over the North Pacific Ocean. J. Geophys. Res. 114. https://doi.org/10.1029/2008JD010417.

Spokes, L.J., Jickells, T.D., 1996. Factors controlling the solubility of aerosol trace metals in the atmosphere and on mixing into seawater. Aquat. Geochem. 1, 355-374.

Srinivas, B., Sarin, M.M., Kumar, A., 2012. Impact of anthropogenic sources on aerosol iron solubility over the Bay of Bengal and the Arabian Sea. Biogeochemistry 110 257-268. https://doi.org/10.1007/s10533-011-9680-1.

Stuut, J.-B.W., Prins, M.A., 2014. The significance of particle size of long-range transported mineral dust. Past Glob. Change. Mag. 22, 70-71. https://doi.org/10.22498/ pages.22.2.70.

Tagliabue, A., Völker, C., 2011. Towards accounting for dissolved iron speciation in global ocean models. Biogeosciences 8, 3025-3039. https://doi.org/10.5194/bg-8 3025-2011.

Tagliabue, A., Aumont, O., DeAth, R., Dunne, J.P., Dutkiewicz, S., Galbraith, E., Misumi, K., Moore, J.K., Ridgwell, A., Sherman, E., Stock, C., Vichi, M., Völker, C., Yool, A., 2016. How well do global ocean biogeochemistry models simulate dissolved iron distributions? Glob. Biogeochem. Cycles 30, 149-174. https://doi.org/10.1002/ 2015 GB005289.

Tagliabue, A., Bowie, A.R., Boyd, P.W., Buck, K.N., Johnson, K.S., Saito, M.A., 2017. The integral role of iron in ocean biogeochemistry. Nature 543, 51-59.

Takahama, S., Gilardoni, S., Russell, L.M., 2008. Single-particle oxidation state and morphology of atmospheric iron aerosols. J. Geophys. Res. 113. https://doi.org/10 1029/2008JD009810.

Ternon, E., Guieu, C., Loÿe-Pilot, M.-D., Leblond, N., Bosc, E., Gasser, B., Miquel, J.-C., Martín, J., 2010. The impact of Saharan dust on the particulate export in the water column of the North Western mediterranean sea. Biogeosciences 7, 809-826. https:// doi.org/10.5194/bg-7-809-2010.

Tovar-Sánchez, A., Arrieta, J.M., Duarte, C.M., Sañudo-Wilhelmy, S.A., 2014. Spatial gradients in trace metal concentrations in the surface microlayer of the mediterranean sea. Front. Mar. Sci. 1. https://doi.org/10.3389/fmars. 2014.00079.

Tran, A., Williams, G., Younus, S., Ali, N.N., Blair, S.L., Nizkorodov, S.A., Al-Abadleh, H.A., 2017. Efficient formation of light-absorbing polymeric nanoparticles from the reaction of soluble Fe(III) with C4 and C6 dicarboxylic acids. Environ. Sci. Technol. 51, 9700-9708. https://doi.org/10.1021/acs.est.7b01826.

Turekian, K.K., 1977. The fate of metals in the oceans. Geochim. Cosmochim. Acta 41, 1139-1144. https://doi.org/10.1016/0016-7037(77)90109-0.

van der Does, M., Knippertz, P., Zschenderlein, P., Giles Harrison, R., Stuut, J.-B.W., 2018 The mysterious long-range transport of giant mineral dust particles. Sci. Adv. 4, eaau2768. https://doi.org/10.1126/sciadv.aau2768.

van Hulten, M.M.P., Sterl, A., Tagliabue, A., Dutay, J.-C., Gehlen, M., de Baar, H.J.W., Middag, R., 2013. Aluminium in an ocean general circulation model compared with the West Atlantic Geotraces cruises. J. Mar. Syst. 126, 3-23. https://doi.org/10. 1016/j.jmarsys.2012.05.005.

Verwey, E.J.W., 1947. Theory of the stability of lyophobic colloids. J. Phys. Chem. 51, 631-636. https://doi.org/10.1021/j150453a001.

Vinatier, V., Wirgot, N., Joly, M., Sancelme, M., Abrantes, M., Deguillaume, L., Delort, A. M., 2016. Siderophores in cloud waters and potential impact on atmospheric chemistry: production by microorganisms isolated at the Puy de Dôme Station. Environ. Sci. Technol. 50, 9315-9323. https://doi.org/10.1021/acs.est.6b02335.

Voelker, B.M., Sedlak, D.L., 1995. Iron reduction by photoproduced superoxide in seawater. Mar. Chem. 50, 93-102. https://doi.org/10.1016/0304-4203(95)00029-Q.

Völker, C., Tagliabue, A., 2015. Modeling organic iron-binding ligands in a three-dimensional biogeochemical ocean model. Mar. Chem. 173, 67-77. https://doi.org/10. 1016/j.marchem.2014.11.008. 
von der Heyden, B.P., Roychoudhury, A.N., Mtshali, T.N., Tyliszczak, T., Myneni, S.C.B., 2012. Chemically and geographically distinct solid-phase iron pools in the Southern Ocean. Science 338, 1199-1201. https://doi.org/10.1126/science.1227504.

Vraspir, J.M., Butler, A., 2009. Chemistry of marine ligands and siderophores. Annu. Rev. Mar. Sci. 1, 43.

Waeles, M., Baker, A.R., Jickells, T., Hoogewerff, J., 2007. Global dust teleconnections: aerosol iron solubility and stable isotope composition. Environ. Chem. 4, 233. https://doi.org/10.1071/EN07013.

Wagener, T., Pulido-Villena, E., Guieu, C., 2008. Dust iron dissolution in seawater: results from a one-year time-series in the mediterranean sea. Geophys. Res. Lett. 35. https:// doi.org/10.1029/2008GL034581.

Wagener, T., Guieu, C., Leblond, N., 2010. Effects of dust deposition on iron cycle in the surface mediterranean sea: results from a mesocosm seeding experiment. Biogeosciences 7, 3769-3781. https://doi.org/10.5194/bg-7-3769-2010.

Wang, R., Balkanski, Y., Boucher, O., Bopp, L., Chappell, A., Ciais, P., Hauglustaine, D., Peñuelas, J., Tao, S., 2015. Sources, transport and deposition of iron in the global atmosphere. Atmos. Chem. Phys. 15, 6247-6270. https://doi.org/10.5194/acp-156247-2015.

Wang, W.-L., Armstrong, R.A., Cochran, J.K., Heilbrun, C., 2016. 230 Th and 234 Th as coupled tracers of particle cycling in the ocean: a maximum likelihood approach. Deep-Sea Res. I 111, 61-70. https://doi.org/10.1016/j.dsr.2016.02.003.

Weber, L., Völker, C., Schartau, M., Wolf-Gladrow, D.A., 2005. Modeling the speciation and biogeochemistry of iron at the bermuda atlantic time-series study site. Glob. Biogeochem. Cycles 19. https://doi.org/10.1029/2004GB002340.

Wells, M.L., Bruland, K.W., 1998. An improved method for rapid preconcentration and determination of bioactive trace metals in seawater using solid phase extraction and high resolution inductively coupled plasma mass spectrometry. Mar. Chem. 63, 145-153. https://doi.org/10.1016/S0304-4203(98)00058-9.

Wilhelm, S.W., Trick, C.G., 1994. Iron-limited growth of cyanobacteria: multiple siderophore production is a common response. Limnol. Oceanogr. 39, 1979-1984.

Willey, J.D., Kieber, R.J., Seaton, P.J., Miller, C., 2008. Rainwater as a source of Fe (II)stabilizing ligands to seawater. Limnol. Oceanogr. 53, 1678.

Wu, J., Boyle, E.A., 1998. Determination of iron in seawater by high-resolution isotope dilution inductively coupled plasma mass spectrometry after $\mathrm{Mg}(\mathrm{OH}) 2$ coprecipitation. Anal. Chim. Acta 367, 183-191. https://doi.org/10.1016/S0003-2670(98) 00145-7.
Wu, J., Rember, R., Cahill, C., 2007. Dissolution of aerosol iron in the surface waters of the North Pacific and North Atlantic oceans as determined by a semicontinuous flowthrough reactor method. Glob. Biogeochem. Cycles 21https://doi.org/10.1029/ 2006GB002851. GB4010.

Wurl, O., Ekau, W., Landing, W.M., Zappa, C.J., 2017. Sea surface microlayer in a changing ocean - a perspective. Elem Sci Anth 5, 31. https://doi.org/10.1525/ elementa.228.

Wuttig, K., Wagener, T., Bressac, M., Dammshäuser, A., Streu, P., Guieu, C., Croot, P.L., 2013. Impacts of dust deposition on dissolved trace metal concentrations ( $\mathrm{Mn}, \mathrm{Al}$ and Fe) during a mesocosm experiment. Biogeosciences 10, 2583-2600. https://doi.org/ 10.5194/bg-10-2583-2013.

Wuttig, K., Townsend, A.T., van der Merwe, P., Gault-Ringold, M., Holmes, T., Schallenberg, C., Latour, P., Tonnard, M., Rijkenberg, M.J.A., Lannuzel, D., Bowie, A.R., 2019. Critical evaluation of a seaFAST system for the analysis of trace metals in marine samples. Talanta 197, 653-668. https://doi.org/10.1016/j.talanta.2019.01. 047.

Ye, Y., Völker, C., 2017. On the role of dust-deposited lithogenic particles for iron cycling in the tropical and subtropical Atlantic. Glob. Biogeochem. Cycles 31, 1543-1558. https://doi.org/10.1002/2017GB005663.

Ye, Y., Völker, C., Wolf-Gladrow, D.A., 2009. A model of Fe speciation and biogeochemistry at the Tropical Eastern North Atlantic Time-Series Observatory site. Biogeosciences 6, 2041-2061. https://doi.org/10.5194/bg-6-2041-2009.

Ye, Y., Wagener, T., Völker, C., Guieu, C., Wolf-Gladrow, D.A., 2011. Dust deposition: iron source or sink? A case study. Biogeosciences 8, 2107-2124. https://doi.org/10.5194/ bg-8-2107-2011.

Zhang, Z., Liu, L., Liu, C., Cai, W., 2003. Studies on the sea surface microlayer. J. Colloid Interface Sci. 264, 148-159. https://doi.org/10.1016/S0021-9797(03)00390-4.

Zhu, X., Prospero, J.M., Savoie, D.L., Millero, F.J., Zika, R.G., Saltzman, E.S., 1992. Photoreduction of iron(III) in marine mineral aerosol solutions. J. Geophys. Res. 98, 9039. https://doi.org/10.1029/93JD00202.

Zhuang, G., Duce, R.A., Kester, D.R., 1990. The dissolution of atmospheric iron in surface seawater of the open ocean. J. Geophys. Res. 95, 16207. https://doi.org/10.1029/ JC095iC09p16207.

Zhuang, G., Yi, Z., Duce, R.A., Brown, P.R., 1992. Link between iron and sulphur cycles suggested by detection of $\mathrm{Fe}(\mathrm{n})$ in remote marine aerosols. Nature 355, 537-539. https://doi.org/10.1038/355537a0. 